\title{
Artikel Review: Potensi Kolagen sebagai Bahan Aktif Sediaan Farmasi
}

\author{
Vicania Raisa Rahman ${ }^{1}$, Marline Abdassah Bratadiredja², Nyi Mekar Saptarini \\ ${ }_{1}^{1}$ Program Studi Sarjana Farmasi, Fakultas Farmasi, Universitas Padjadjaran, \\ 2Departemen Farmasetika dan Teknologi Farmasi, Fakultas Farmasi, Universitas Padjadjaran, \\ 3Departemen Departemen Analisis Farmasi dan Kimia Medisinal, Universitas Padjadjaran, \\ email: vicania17001@mail.unpad.ac.id
}

(Submit 4/6/2021, Revisi 29/7/2021, Diterima 2/8/2021, Terbit 6/8/2021)

\begin{abstract}
Abstrak
Kolagen adalah protein dengan kandungan sekitar $30 \%$ atau lebih dari protein total yang terdapat di kulit, tendon, tulang rawan, dan organ. Ada 29 jenis kolagen yang telah ditemukan dengan struktur dan urutan asam amino yang berbeda. Kolagen mempunyai karakteristik fisikokimia yang baik yaitu bersifat biokompatibel, dapat terurai di dalam tubuh (biodegradable), antigenisitas yang rendah, dan nontoksik dengan berbagai aktivitas yang dapat mendukungnya sebagai sediaan farmasi. Selain itu, sumber kolagen juga mudah didapatkan yaitu diisolasi dari hewan vertebrata, terutama mamalia dengan fungsi utama dalam tubuh sebagai pembangun tulang, sendi, dan otot. Review artikel dilakukan untuk mengumpulkan informasi tentang kolagen yang memiliki berbagai aktivitas sebagai sediaan farmasi. Artikel ini membahas tentang potensi kolagen sebagai sediaan farmasi untuk kesehatan dengan sumber yang mudah didapatkan dan peran pentingnya dalam tubuh. Hasil yang didapatkan adalah kolagen memiliki banyak peran dalam tubuh sehingga memiliki banyak aktivitas untuk kesehatan, terutama sebagai antiinflamasi, menyembuhkan luka, kondroprotektif, pertumbuhan dan homeostasis kulit, tendon, tulang, otot, dan saraf, dan antikanker. Kolagen sangat mempengaruhi tubuh dan dapat dijadikan sediaan farmasi sebagai suplemen, kosmetik, ataupun scaffolding material untuk kesehatan.
\end{abstract}

Kata kunci: Asam amino, kesehatan, kolagen, sediaan farmasi. 


\section{Pendahuluan}

Kolagen merupakan protein yang terdapat di kulit, tendon, tulang rawan, dan organ dengan kandungan sekitar $30 \%$ atau lebih dari protein total. Kolagen terdapat pada manusia dan hewan [1,2]. Saat ini, kolagen telah ditemukan mempunyai 29 jenis yaitu kolagen tipe I-XXIX dengan struktur dan urutan asam amino yang berbeda [3]. Pada umumnya, kolagen diisolasi dari sumber alami. Sumber alami dapat diperoleh dari sumber hewani, khususnya dari hewan veterbrata [4]. Biasanya kolagen diisolasi dari hewan mamalia atau pisces (ikan). Hal ini karena hewan mamalia mengandung asam amino utama yang tinggi dalam struktur kolagen, yaitu hidroksiprolin. Sedangkan, hewan pisces (ikan) memiliki keunggulan dibandingkan hewan lain yaitu dapat mengurangi limbah dari pengolahan ikan karena limbah pengolahan ikan seperti sisik atau tulang dapat dimanfaatkan juga sebagai sumber kolagen, tidak menimbulkan risiko penyakit seperti foot and mouth disease atau bovine spongiform encephalopathy, dan telah dianggap sebagai GRAS (Generally Recognized As Safe) oleh FDA $[5,6]$.

Kolagen mempunyai peran penting dalam tubuh yaitu sebagai pembangun tulang, gigi, sendi, otot, dan kulit sehingga diperlukan oleh tubuh [1]. Namun, kolagen dapat berkurang karena beberapa faktor seperti penuaan, banyak terpapar sinar ultraviolet, merokok, dan diabetes [7-9]. Kekurangan kolagen ini dapat menyebabkan tubuh menjadi sulit untuk melaksanakan perannya sehingga terjadilah gangguan dalam tubuh seperti penuaan kulit, inflamasi, penyembuhan luka lebih lambat, massa otot menurun, dan tulang rawan melemah [nyeri sendi atau osteoartritis) [7,9-13]. Oleh karena itu, dibutuhkan kolagen dari luar tubuh untuk dapat mencegah hal tersebut terjadi [14].

Kolagen memiliki berbagai aktivitas seperti aktivitas antioksidan, antiinflamasi, antidiabetes, dan antikanker sehingga banyak digunakan dalam sediaan farmasi seperti kosmetik, biomedis, ataupun suplemen [14-19]. Selain itu, kolagen juga mempunyai karakteristik fisikokimia yang baik yaitu bersifat biokompatibel, biodegradable, antigenisitas yang rendah, dan nontoksik sehingga memiliki keunggulan tersendiri [19]. Karena kolagen mempunyai berbagai macam aktivitas yang dapat mencegah ataupun mengobati berbagai penyakit dan sumber kolagen juga mudah untuk ditemukan maka kolagen menjadi alternatif yang baik untuk pengobatan saat ini. Oleh karena itu, banyak peneliti tertarik melakukan penelitian tentang potensi kolagen sebagai bahan aktif sediaan farmasi [14-16].

Telah banyak peneliti yang melakukan review tentang kolagen baik sebagai kosmetik, biomedis, ataupun suplemen. [20] melakukan review kolagen sebagai suplemen. [6] melakukan review kolagen sebagai kosmetik. [21] melakukan review kolagen sebagai biomedis. [22] melakukan review kolagen dari ikan sebagai biomedis. Dari review yang telah ada, tidak banyak yang membahas aplikasi semua jenis kolagen. Biasanya peneliti hanya membahas kolagen tipe I dan II. Selain itu, kini banyak peneliti yang telah meneliti potensi kolagen yang baru. Oleh karena itu, dilakukan review potensi semua jenis kolagen sebagai bahan aktif sediaan farmasi sebagai kosmetik, biomedis, ataupun suplemen dengan keterbaruan penelitian yang telah dilakukan. 


\section{Metode}

Penulisan review ini dimulai pada Maret 2021, melalui penelusuran data dan informasi dari situs pencarian Google Scholar dengan kata kunci "collagen", "collagen potency", "collagen potencial", "kolagen", dan "potensi kolagen". Kriteria inklusi pada review ini adalah artikel dalam bahasa Indonesia dan bahasa Inggris, merupakan hasil penelitian uji in silico, in vitro, dan in vivo, dan berkaitan dengan kolagen sebagai zat aktif. Dan kriteria eksklusi adalah artikel yang tidak tersedia dalam full paper secara gratis, berkaitan dengan kolagen di luar bidang farmasi, dan merupakan hasil review artikel terkait dengan kolagen. Artikel yang memenuhi kriteria adalah 93 artikel.

\section{Hasil}

Kolagen mempunyai banyak peran dalam tubuh sehingga memiliki banyak aktivitas dalam bidang kesehatan. Potensi kolagen sebagai sediaan farmasi, antara lain adalah antioksidan, antiinflamasi, antidiabetes, antikanker, antimikroba, antiaging, kondroprotektif, pencegahan diastasis rekti, perawatan rambut, stabilisasi plak aterosklerosis, jantung, pertumbuhan dan homeostasis mata, gigi, tendon, saraf, otot, kulit, dan tulang, pematangan neuromuscular junction (NMJ), dan lainnya.

Perbedaan kolagen tipe I-XXIX adalah berdasarkan urutan asam amino, struktur, dan fungsinya masing-masing [5]. Protein kolagen mempunyai urutan struktur polipeptida Gly-X-Y. Pada umumnya, urutan tripeptida tersebut terus berulang di sepanjang rantai 1000 asam amino. Sebagian besar urutan tripeptida atau sekitar $20 \%$ tersusun atas prolin dan hidroksiprolin [19]. Masing-masing tipe kolagen dapat dibentuk dari tiga rantai identik (homotrimer) atau dua atau tiga rantai berbeda (heterotrimer) tergantung dari tipe kolagen tersebut. Setiap rantai mengandung 1050 asam amino [2]. Berdasarkan fungsinya, pada umumnya semua tipe kolagen berperan dalam menyembuhkan luka luar karena sebagian besar kolagen terdapat di kulit. Namun, kolagen tersebar di seluruh tubuh sehingga memiliki banyak peran lain. Potensi kolagen sebagai bahan aktif sediaan farmasi terdapat pada Tabel 2.

Tabel 2. Potensi Kolagen sebagai Bahan Aktif Sediaan Farmasi

\begin{tabular}{|c|c|c|c|c|c|}
\hline $\begin{array}{c}\text { Tipe } \\
\text { Kolagen }\end{array}$ & Struktur & $\begin{array}{c}\text { Distribusi di } \\
\text { Jaringan }\end{array}$ & & Fungsi/Aplikasi & Referensi \\
\hline I & $\begin{array}{l}\text { Fibril- } \\
\text { forming } \\
\text { collagen }\end{array}$ & $\begin{array}{l}\text { Sebagian besar } \\
\text { jaringan ikat, seperti } \\
\text { kulit, tulang, tendon, } \\
\text { dermis, ligamen, } \\
\text { kornea, dan } \\
\text { pembuluh darah. }\end{array}$ & $\begin{array}{l}1 . \\
2 . \\
3 . \\
4 . \\
5 . \\
6 . \\
7 . \\
8 .\end{array}$ & $\begin{array}{l}\text { Antioksidan. } \\
\text { Pencegahan } \\
\text { diastasis rekti. } \\
\text { Kondroprotektif. } \\
\text { Antiinflamasi } \\
\text { Antiaging. } \\
\text { Scaffolding material. } \\
\text { Menyembuhkan luka. } \\
\text { Menyembuhkan } \\
\text { ruptur rotator cuff } \\
\text { tendon. }\end{array}$ & {$[14,23-29]$} \\
\hline
\end{tabular}




\section{Tulang rawan hialin,}

Fibril- intervertebral disc, 1. Kondroprotektif.

II forming vitreous body pada collagen mata, dan telinga bagian dalam. pada osteoarthritis.

1. Pencegahan

Sebagian besar jaringan ikat, seperti

Fibrilkulit, tulang, tendon,

III forming collagen dermis, kornea, ligamen, pembuluh darah. dan

diastasis rekti.

2. Menyembuhkan luka.

3. Kondroprotektif.

$[23,26,29,33-$

4. Perbaikan rotator cuff tendon.

36]

5. Terlibat

dalam pembentukan tulang.

1. Berpotensi sebagai vascular graft material untuk terapi

Network-

IV forming collagen

Membran basal. penyakit arteri koroner.

2. Berpotensi sebagai terapi fibrosis hati.
3. Berperan dalam penyembuhan luka.

1. Berperan dalam fibrillogenesis stroma

Fibril- Jaringan ikat, tulang kornea. collagen

rawan hialin, dan sistem saraf.
2. Berperan dalam pembentukan tendon. 
1. Kondroprotektif.

2. Mungkin berperan dalam penyembuhan luka.

3. Berpotensi untuk perkembangan terapi transplantasi islet sebagai terapi diabetes tipe 1.

4. Berperan dalam fibrillogenesis tendon.

5. Berperan dalam regenerasi otot.

6. Berperan dalam homeostasis otot.

VI fillament $\begin{aligned} & \text { rawan hialin, } \\ & \text { forming } \\ & \text { collagen } \\ & \text { saraf perifer, dan } \\ & \text { pembuluh darah. }\end{aligned}$

$$
\text { Anchoring Kulit, dermo- }
$$
collagen epidermal junction.

7. Kolagen ini berperan dalam perakitan dan pematangan tulang.
8. Berperan dalam regenerasi saraf perifer.

9. Berperan dalam melindungi SSP selama penuaan fisiologis [memori].

10. Berperan dalam pembentukan kekuatan tarik kulit.

11. Berpotensi sebagai terapi rambut rontok.

12. Berpotensi sebagai antimikroba.

1. Berpotensi dalam penyembuhan luka.

2. Berpotensi sebagai terapi recessive dystrophic epidermolysis bullosa [RDEB].

3. Berperan dalam pembentukan gigi. 


\begin{tabular}{|c|c|c|c|c|c|}
\hline VIII & $\begin{array}{l}\text { Hexagonal } \\
\text { network } \\
\text { forming } \\
\text { collagen }\end{array}$ & $\begin{array}{l}\text { Di banyak jaringan, } \\
\text { terutama } \\
\text { endotelium. }\end{array}$ & 3. & 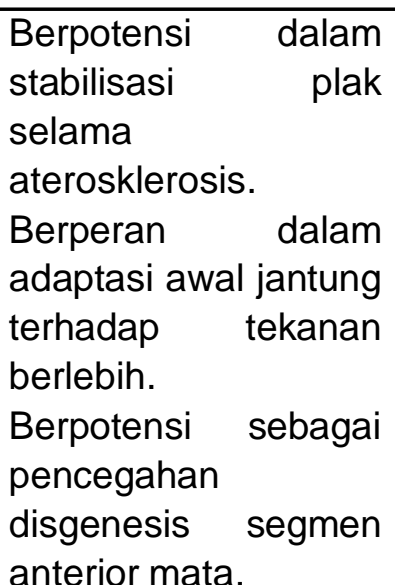 & {$[23,39,57,58]$} \\
\hline IX & FACIT & $\begin{array}{l}\text { Tulang rawan hialin, } \\
\text { vitreous body pada } \\
\text { mata, kornea, dan } \\
\text { intervertebral disk. }\end{array}$ & \multicolumn{2}{|c|}{ Kondroprotektif. } & {$[23,39,59]$} \\
\hline$X$ & $\begin{array}{l}\text { Hexagonal } \\
\text { network } \\
\text { forming } \\
\text { collagen }\end{array}$ & $\begin{array}{l}\text { Tulang rawan } \\
\text { hipertrofik. }\end{array}$ & $\begin{array}{l}1 . \\
2 .\end{array}$ & $\begin{array}{l}\text { Kondroprotektif. } \\
\text { Berperan dalam } \\
\text { osifikasi endokondral. }\end{array}$ & {$[23,39,60,61]$} \\
\hline XI & $\begin{array}{l}\text { Fibril- } \\
\text { forming } \\
\text { collagen }\end{array}$ & $\begin{array}{l}\text { Tulang rawan hialin, } \\
\text { intervertebral disc, } \\
\text { dan telinga bagian } \\
\text { dalam. }\end{array}$ & $\begin{array}{l}1 . \\
2 .\end{array}$ & $\begin{array}{l}\text { Kondroprotektif. } \\
\text { Berperan dalam } \\
\text { perkembangan } \\
\text { tendon. } \\
\text { Berpotensi mencegah } \\
\text { chondrodysplasia dan } \\
\text { kondrodistrofi. } \\
\text { Berperan dalam } \\
\text { homeostatis annulus } \\
\text { fibrosus. }\end{array}$ & $\begin{array}{c}{[23,39,41,62,} \\
63]\end{array}$ \\
\hline
\end{tabular}




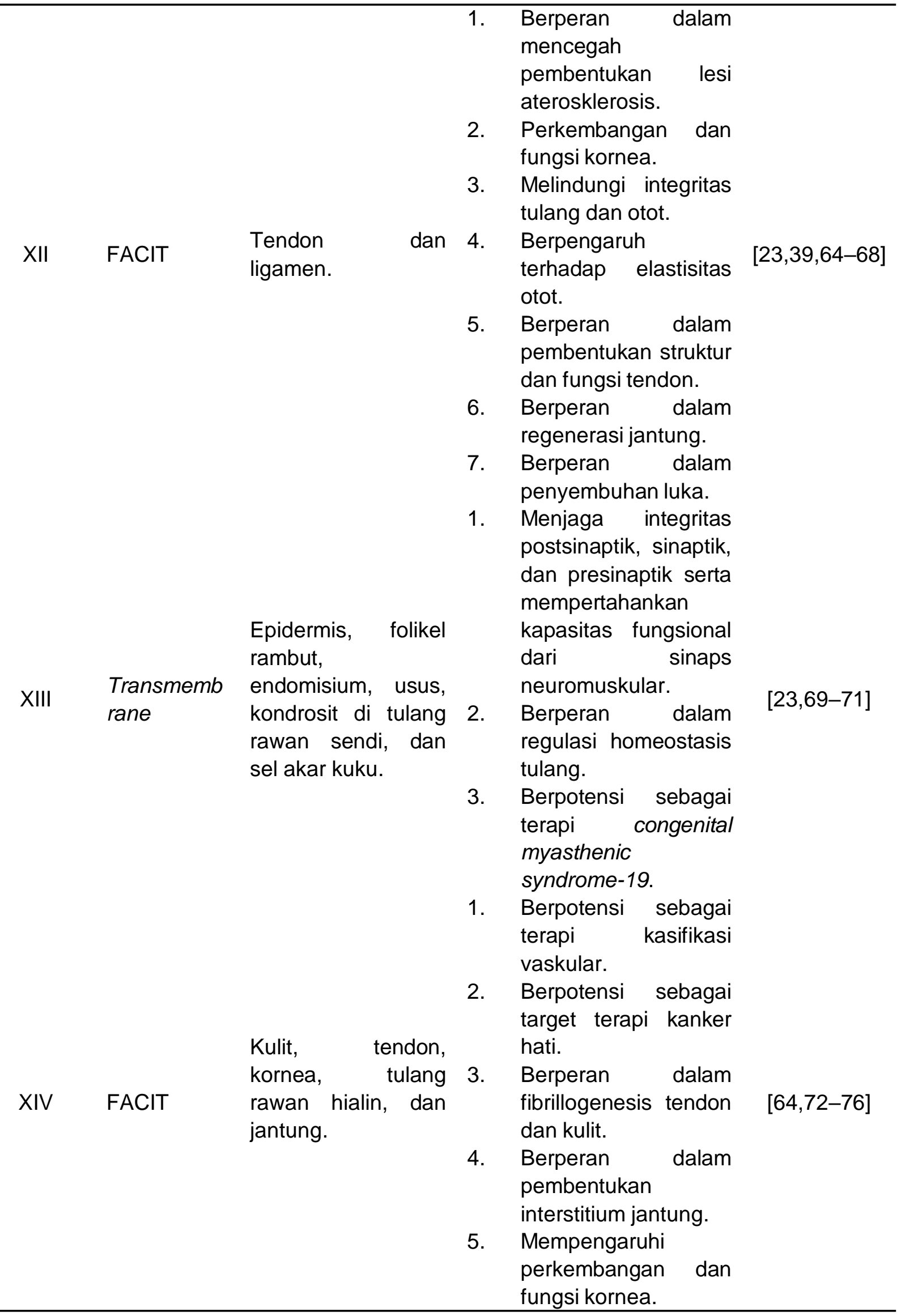




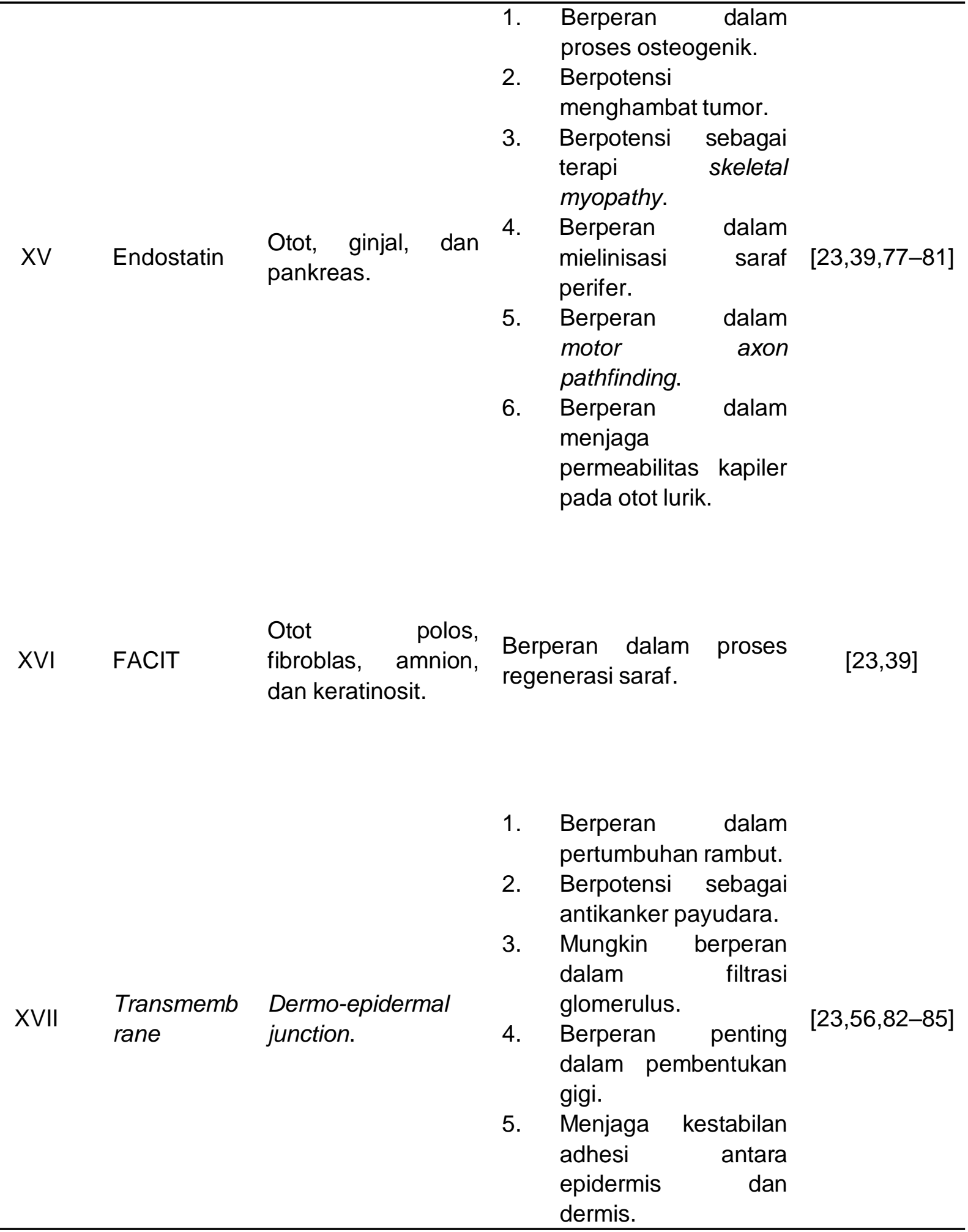


1. Antikanker.

2. Berpotensi sebagai antidiabetes.

3. Regenerasi hati.

4. Terlibat dalam pembentukan retina $[17,18,23,81$,

XVIII Endostatin Membran basal. mata. 86-89]

5. Menjaga permeabilitas kapiler pada otot lurik.

6. Terlibat dalam perkembangan gigi.

Pembuluh darah, zona membran basal saraf dan otot dari otot rangka, limpa, kulit, ginjal, XIX FACIT usus besar, prostat dan di hipokampus di otak. Dapat diisolasi dari

1. Terlibat dalam perkembangan otak.

2. Antikanker.

3. Berperan dalam $[39,90,91]$ fisiologi dan diferensiasi otot. rhabdomyosarcoma manusia.

Epitel kornea, kulit embrio, tulang rawan sternum, dan tendon.
Membentuk jembatan yang menghubungkan kolagen fibrillar seperti tipe XII dan XIV dan berperan dalam adhesi sel, migrasi, diferensiasi, dan pensinyalan [komunikasi antar sel].

Jantung, plasenta, Mungkin memiliki peran otot rangka, dan dalam perakitan pembuluh ginjal.

Myotendinous junction, jantung, otot rangka, XXII FACIT permukaan artikular tulang rawan, dan cairan tulang rawan-sinovial. darah.

[39,92]
1. Mungkin berperan dalam menjaga perlekatan otot.
2. Berperan dalam menjaga struktural jaringan ikat.

[93-96]

3. Berperan dalam menjaga integritas vaskular. 


\begin{tabular}{|c|c|c|c|c|}
\hline XXIII & $\begin{array}{l}\text { Transmemb } \\
\text { rane }\end{array}$ & $\begin{array}{l}\text { Epidermis, lidah, } \\
\text { usus, paru-paru, } \\
\text { otak, ginjal, dan } \\
\text { prostat, } \\
\text { jantung. }\end{array}$ & $\begin{array}{l}\text { Berpotensi menyembuhkan } \\
\text { luka. }\end{array}$ & {$[23,97]$} \\
\hline XXIV & $\begin{array}{l}\text { Fibril- } \\
\text { forming } \\
\text { collagen }\end{array}$ & $\begin{array}{l}\text { Otak, kornea mata, } \\
\text { dan tulang. }\end{array}$ & 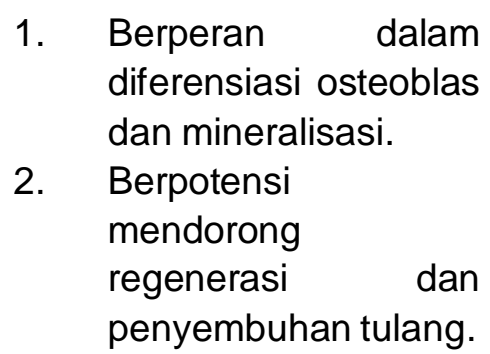 & {$[23,92,98]$} \\
\hline XXV & $\begin{array}{l}\text { Transmemb } \\
\text { rane }\end{array}$ & $\begin{array}{l}\text { Otak, jantung, } \\
\text { testis, dan neuron, } \\
\text { dan otot rangka. }\end{array}$ & 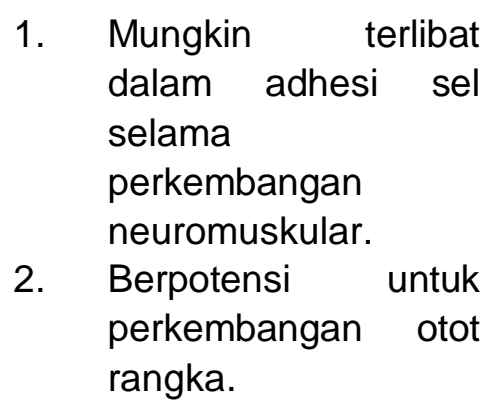 & {$[23,99,100]$} \\
\hline XXVI & $\begin{array}{l}\text { Beaded } \\
\text { fillament } \\
\text { forming } \\
\text { collagen }\end{array}$ & Testis dan ovarium. & $\begin{array}{l}\text { Berperan dalam } \\
\text { perkembangan testis dan } \\
\text { ovarium. }\end{array}$ & {$[23,101]$} \\
\hline XXVII & $\begin{array}{l}\text { Fibril- } \\
\text { forming } \\
\text { collagen }\end{array}$ & $\begin{array}{l}\begin{array}{l}\text { Tulang rawan } \\
\text { embrionik } \\
\text { lapisan sel }\end{array} \\
\text { epitel } \\
\text { [lambung, } \\
\text { paru, kulit, dan gigi]. }\end{array}$ & Kondroprotektif. & {$[23,102]$} \\
\hline XXVIII & $\begin{array}{l}\text { Beaded } \\
\text { fillament } \\
\text { forming } \\
\text { collagen }\end{array}$ & $\begin{array}{l}\text { Saraf perifer dan } \\
\text { paru-paru. }\end{array}$ & $\begin{array}{l}\text { Berpotensi untuk perbaikan } \\
\text { cedera jaringan paru-paru. }\end{array}$ & {$[23,103]$} \\
\hline XXIX & $\begin{array}{l}\text { Beaded } \\
\text { fillament } \\
\text { forming } \\
\text { collagen }\end{array}$ & $\begin{array}{l}\text { Kulit, paru-paru, dan } \\
\text { saluran } \\
\text { pencernaan. }\end{array}$ & $\begin{array}{l}\text { Mungkin berperan dalam } \\
\text { organisasi } \\
\text { jaringan. }\end{array}$ & {$[104,105]$} \\
\hline
\end{tabular}




\section{Pembahasan}

\section{Antioksidan}

Antioksidan adalah molekul yang mampu memperlambat atau mencegah efek dari ROS (radical oxygen species). ROS dapat merusak DNA, lipid, dan protein karena rusaknya jaringan akibat peningkatan ROS [106]. Kolagen tipe I memiliki aktivitas antioksidan. Dalam penelitian ini, kolagen tipe I didapatkan dari Todarodes pacificus. Kolagen ini mempunyai kandungan antioksidan dari pemeriksaan kemampuan mengkelat tembaga, mengkelat besi, DPPH (2,2-diphenyl-1-picrylhydrazy) Radical Scavenging Activity, Hydrogen Peroxide Scavenging Activity dan Hydroxyl Radical Scavenging Activity, dan ABTS (2,2 azinobis (3-etilbenzotiazolin)-6-asam sulfonat)) Radical Scavenging Activity [25].

Tembaga merupakan kofaktor untuk enzim di kulit seperti lisil oksidase yang terlibat dalam produksi kolagen dan elastin, dan superoksida dismutase (enzim antioksidan). Kemampuan pengkelat kolagen tipe I sangat bergantung pada konsentrasi fraksi hidrolisat (bergantung pada berat molekul dan komposisi asam amino). Umumnya, jika panjang peptida terlalu pendek, kelasi tidak stabil. Asam amino dalam kolagen tipe I yang memiliki aktivitas pengkelat yang tinggi adalah histidin karena mempunyai cincin imidazol dan secara langsung berimplikasi pada pengikatan peptida pada tembaga. Kolagen ini mengandung $1.78 \mathrm{nM}$ histidin [25].

Besi berperan dalam pembuatan ROS. Sehingga perlu diikat agar tidak terjadinya efek ROS. Kemampuan kelat besi kolagen ini relatif rendah dibandingkan dengan EDTA. Memang, kemampuan kelat EDTA dan F3 hampir 50\% masing-masing pada 50 dan $200 \mathrm{~g} / \mathrm{ml}$. Asam amino dalam kolagen tipe I yang berperan adalah Glu (glutamat), Asp (aspartat), Ser (serin), dan His (histidin) yang dapat mengikat besi karena Glu, Asp, Ser mengkelat besi dengan gugusnya yang kaya oksigen seperti oksigen dari gugus karboksil dan His mengkelat besi dengan gugus kaya nitrogen dari imidazol [25].

DPPH Radical Scavenging Activity adalah pemeriksaan antioksidan yang paling banyak dilakukan. Pada pemeriksaan ini, $\mathrm{IC}_{50}$ (the half maximal inhibitory concentration) dari kolagen tipe I adalah $417,43 \mu \mathrm{g} / \mathrm{ml}$ yang lebih besar dari asam askorbat yaitu 9.66 $\mu \mathrm{g} / \mathrm{ml}$. Mekanisme kerja metode ini adalah ketika DPPH bertemu dengan zat pendonor proton seperti antioksidan, radikal akan terbawa/terbuang (scanvenged). Kapasitas antioksidan dapat dipengaruhi oleh konformasi peptida, kelimpahan, dan posisi asam amino tertentu dalam urutan peptida. Asam amino dalam kolagen tipe I yang berperan dalam hal ini adalah Gly dan Pro yang meningkatkan kapasitas pembersihan radikal [25]. 
Hydrogen Peroxide Scavenging Activity dan Hydroxyl Radical Scavenging Activity adalah pemeriksaan antioksidan yang saling berhubungan karena hidrogen peroksida merupakan molekul yang tidak terlalu reaktif, tetapi beracun bagi sel ketika terurai menjadi radikal hidroksil. Radikal hidroksil adalah spesies paling reaktif, yang terbentuk dari anion superoksida dan hidrogen peroksida dengan adanya besi. Molekul ini dapat merusak biomolekul yang berdekatan dalam sel hidup dan dapat menyebabkan penuaan dini, perkembangan kanker, dan beberapa penyakit. Kapasitas antioksidan sangat bergantung pada komposisi asam amino dan jumlah asam amino hidrofobik. Polipeptida dalam kolagen tipe I yang digunakan sebagai hydrogen peroxide dan hydroxyl scavenging mungkin terkait dengan kapasitas pengikatan besinya. Pada pemeriksaan Hydrogen Peroxide Scavenging Activity, $\mathrm{IC}_{50}$ dari kolagen tipe I adalah $254,88 \mu \mathrm{g} / \mathrm{ml}$ yang lebih besar dari asam askorbat yaitu $125.64 \mu \mathrm{g} / \mathrm{ml}$. Dan pada pemeriksaan Hydroxyl Radical Scavenging Activity, IC $_{50}$ dari kolagen tipe I adalah 149,9 $\mu \mathrm{g} / \mathrm{ml}$ yang lebih rendah dari asam askorbat yaitu $212.9 \mu \mathrm{g} / \mathrm{ml}$ [25].

ABTS Radical Scavenging Activity adalah salah satu pemeriksaan antioksidan yang melihat kemampuan suatu zat untuk menyumbangkan atom elektron dan hidrogen ke spesies radikal ABTS yang tidak aktif. Pada pemeriksaan ini, $\mathrm{IC}_{50}$ dari kolagen tipe I adalah $1,306 \mathrm{mg} / \mathrm{ml}$ yang lebih besar dari asam askorbat yaitu $0.340 \mathrm{mg} / \mathrm{ml}$. Asam amino dalam kolagen tipe I yang berperan adalah Gly (glisin), Pro (prolin), dan Phe (fenilalanin). Gly (glisin) dan Pro (prolin) dapat meningkatkan kapasitas pembersihan radikal dari beberapa peptida. Sedangkan Phe (fenilalanin) dan Gly (glisin) bertindak sebagai scavenging radikal langsung karena kemampuannya untuk mendonorkan proton sehingga elektron tidak berpasangan atau radikal tidak reaktif [25].

\section{Antiinflamasi}

Antiinflamasi adalah suatu zat yang dapat menekan atau mengurangi peradangan [107]. Kolagen yang memiliki aktivitas ini adalah kolagen tipe I dan II sebagai pengobatan nyeri pada osteoarthritis [24,30]. Pada osteoarthritis, akan terjadi peradangan. Pada saat itu, tubuh akan memproduksi lebih banyak sel di dalam dan di sekitar sendi. Sel-sel ini melepaskan zat peradangan ke dalam cairan sinovial, pelumas yang memungkinkan persendian bergerak dengan lancar. Selama osteoartritis, cairan sinovial menjadi kurang kental dan zat inflamasi ini bersentuhan langsung dengan sel saraf sensorik di sendi, menghasilkan sensasi nyeri [108].

Kolagen tipe I yang diisolasi dari sapi berperan dalam mengurangi nyeri. Mekanisme kerjanya adalah dengan cara menurunkan protein TNF (tumor necrosis factor). Hiperplasia sinovial terkait trauma berkurang pada tikus yang diberi suplemen kolagen tipe I. Efek ini terjadi bersamaan dengan penurunan ekspresi TNF sinovial [24].

Kolagen tipe II diuji pada pasien osteoarthritis. Pasien diberikan $10 \mathrm{mg} / \mathrm{hari}$ kolagen tipe II yang diisolasi dari tulang rawan ayam. Hasilnya adalah kolagen ini mengurangi nyeri sendi. Mekanisme kerjanya adalah kolagen ini akan berinteraksi dengan Peyer's patches di usus yang akan mencegah serangan sel T ke serat kolagen di tulang rawan. Proses di Peyer's patches, juga dikenal sebagai toleransi oral untuk menghindari pengenalan kolagen tipe 2 di tulang rawan [30]. 


\section{Antidiabetes}

Antidiabetes adalah senyawa yang dapat menurunkan kadar gula darah. Diabetes memiliki dua jenis yaitu diabetes tipe 1 dan tipe 2 [109]. Kolagen yang memiliki aktivitas ini adalah kolagen tipe VI dan XVIII. Kolagen tipe VI dapat berperan sebagai terapi diabetes tipe 1 . Sedangkan kolagen tipe XVIII dapat berperan sebagai terapi diabetes tipe $2[17,44]$.

Kolagen tipe $\mathrm{VI}$ ada pada antarmuka islet-exocrine sehingga dapat berperan dalam menjaga kelangsungan hidup sel islet. Dalam menjaga kelangsungan hidup sel islet, kolagen berperan dalam tiga mekanisme. Kolagen ini menstimulasi penghambatan kematian dari beta-1 integrin. Kolagen ini juga berkontribusi dalam perakitan ulang jaringan islet ECM (extracellular matrix) dan mencegah kematian sel. Selain itu, kolagen ini dapat mengurangi kerentanan pelepasan sitokin yang dapat merusak sel islet karena isolasi islet. Sehingga kolagen ini berpotensi untuk perkembangan terapi transplantasi islet sebagai terapi yang menjanjikan untuk diabetes tipe 1 [44].

Kolagen tipe XVIII mempunyai mekanisme yang berbeda, yaitu dapat meningkatkan pertumbuhan jaringan adiposa dengan mempengaruhi jumlah sel progenitor adiposit dalam epididymal white adipose tissue (eWAT). Selain itu, kolagen ini juga berperan dalam regulasi homeostasis glukosa dan sensitivitas insulin sebagai akibat dari akumulasi lipid ektopik. Kekurangan kolagen ini dapat menyebabkan kerusakan pada perkembangan jaringan adiposa. Pada tikus, akan menyebabkan disfungsi metabolik, lebih khusus lagi pada akumulasi lipid yang abnormal di hati yang dikombinasikan dengan gangguan sensitivitas insulin dan toleransi glukosa [17].

\section{Antikanker}

Antikanker adalah senyawa yang digunakan untuk membunuh atau menghambat tumbuhnya sel kanker [110]. Kolagen yang memiliki aktivitas antikanker adalah kolagen tipe XIV, XV, XVII, XVIII, dan XIX. Secara umum, kolagen dapat menghambat perkembangan kanker dengan menghambat migrasi sel endotel dan menghambat angiogenesis. Sel endotel berperan dalam perkembangan kanker karena sel tumor menyebar ke organ lain dengan penetrasi melalui sel endotel. Sedangkan angiogenesis adalah proses pembentukan pembuluh darah baru yang dapat memberikan makan jaringan kanker sehingga tumor dapat bertahan hidup dan menyebar pada jaringan lain (metastasis) [18,39,75,78,83,90].

Kolagen tipe XIV dapat menjadi target terapi hepatocellular carcinoma. Kolagen ini berperan penting dalam regulasi CSCs (liver cancer stem cells). Apabila ekspresi kolagen ini terganggu akan menyebabkan peningkatan fosforilasi protein ERK (extracellular-regulated signal kinase) untuk mengaktifkan persinyalan ERK yang akan meningkatkan ekspresi NANOG. Hal ini akan mendorong pembaruan diri CSC [75]. 
Kolagen tipe XV dapat menghambat perkembangan tumor dengan menghambat migrasi sel endotel [39]. Adapun penelitian menyatakan bahwa kolagen ini dapat menghambat perkembangan tumor adenokarsinoma pankreas. Mekanisme kerja kolagen ini adalah menstabilkan E-Cad (E-cadherin) dan menghambat epithelial to mesenchymal transition. Adapun saat perkembangan kanker, kurangnya kolagen ini dan hilangnya interaksinya dengan protein lain dapat secara langsung berdampak pada perkembangan tumor. Dan hilangnya kolagen ini dapat menyebabkan invasi dan metastasis kanker yang lebih cepat [78].

Kolagen tipe XVII diuji secara in vitro menggunakan sampel pasien kanker payudara. Ekspresi kolagen yang lebih tinggi mengarah pada prognosis yang lebih baik pada pasien karsinoma invasif payudara. Selain itu, kolagen diuji juga secara in vivo dengan menggunakan mencit. Kolagen ini dapat menekan migrasi dan invasi sel kanker payudara dengan mencegah sel tumor primer keluar ke jaringan payudara di sekitarnya [83].

Kolagen tipe XVIII mempunyai fragmen C-terminal yaitu endostatin. Endostatin menghambat proliferasi sel endotel, migrasi, invasi, dan pembentukan sel kanker. Pada penelitian, digunakan recombinant human (rh)-endostatin yaitu peptida yang dirancang yang diekspresikan dalam Escherichia coli. Uji coba fase III pada pasien dengan NSCLC (non-small cell lung cancer) dengan menggunakan kombinasi rh-endostatin dan kemoterapi berbasis platinum meningkatkan kelangsungan hidup pasien [18]. Sedangkan kolagen tipe XIX mengandung domain C-terminal NC1 yang dapat menurunkan pertumbuhan tumor pada mencit. Penurunan tumor dimediasi dari penghambatan proliferasi, migrasi dan angiogenesis sel tumor [90].

\section{Antimikroba}

Antimikroba adalah senyawa yang dapat menghambat atau mencegah infeksi dari mikroba [111]. Kolagen VI faktor von Willebrand domain tipe A yang diisolasi dari kornea sapi menunjukkan aktivitas antimikroba spektrum luas terhadap bakteri Gram-positif dan Gram-negatif pada infeksi kulit manusia. Kolagen ini termasuk peptida antimikroba yang merupakan molekul kuat dari sistem pertahanan kekebalan bawaan yang memberikan respons cepat dan tidak spesifik terhadap patogen yang menyerang. Kolagen ini dapat berikatan dan bersifat bakterisidal terhadap Streptococcus pneumoniae dan Streptococcus grup A, C, dan D. Selain itu, kolagen ini juga membunuh patogen seperti $S$. aureus, E. coli, dan $P$. aeruginosa dengan destabilisasi membran dan eksudasi sitoplasma dari patogen [52]. 


\section{Antiaging}

Antiaging adalah senyawa yang dapat memperlambat dan mengurangi tanda penuaan penuaan [112]. Pure Gold Collagen ${ }^{\circledR}$ adalah produk minuman kolagen yang mengandung kolagen tipe I yang bersumber dari tulang rawan ikan. Produk ini mempunyai dua mekanisme kerja. Pertama, peptida akan meningkatkan jumlah kolagen di dermis, dan jaringan fibrillar yang ditingkatkan meningkatkan integritas keseluruhan kulit, sehingga mengurangi kerutan. Kedua, jaringan dermal mengandung fibroblas dirangsang oleh peptida kolagen untuk menghasilkan kolagen, elastin, dan asam hialuronat baru. Produk ini dapat meningkatkan densitas kolagen dan kekencangan kulit setelah 12 minggu pemakaian. Selain itu, juga dapat mengurangi kekeringan kulit dan mengurangi tanda-tanda penuaan seperti keriput dan garis lipatan nasolabial setelah 60 hari pemakaian [14]. Selain produk minuman kolagen, kolagen juga dapat berbentuk krim yang mengandung biomimetic collagen. Kolagen ini akan merangsang fibrillogenesis kolagen tubuh dan memastikan pemeliharaan permanen hidrasi kulit [113].

\section{Kondroprotektif}

Kondroprotektif adalah senyawa yang memperbaiki atau mempertahankan tulang rawan sendi dengan melindungi kondrosit. Kondrosit adalah sel yang terdapat di tulang rawan sendi yang berfungsi dalam sintesis dan integritas dari matriks ekstraseluler. Matriks ekstraselular berperan dalam pembentukan struktur tulang rawan dan berpengaruh dalam fungsi tulang rawan. Kolagen yang memiliki aktivitas kondroprotektif adalah tipe I, II, III, VI, IX, X, XI, dan XXVII [24,32,36,39,42,59,60,63,102].

Kerusakan tulang rawan dapat menyebabkan osteoarthritis yaitu radang pada sendi. Kolagen yang berperan dalam kondroprotektif dan mungkin mencegah osteoarthritis adalah kolagen tipe I dan II. Kolagen tipe I yang diisolasi dari sapi dapat melindungi dari penurunan volume dan ketebalan tulang rawan dan merangsang produksi proteoglikan oleh kondrosit pada mencit yang osteoartritis [24]. Kolagen tipe II yang diisolasi dari tulang rawan cumi dapat meningkatkan rasio makrofag $\mathrm{M} 2$, meningkatkan kadar sitokin pro-kondrogenik (TGF- $\beta 1$ dan TGF- $\beta 3$ ) dalam cairan sinovial, dan menghambat apoptosis kondrosit dan produksi MMP-13 pada tikus osteoarthritis [32].

Kolagen tipe III pada mencit berperan dalam perakitan fibril dan fungsi biomekanik dari tulang rawan artikular dan meniskus. Pada tulang rawan artikular, kolagen tipe III memediasi tahap awal fibrillogenesis kolagen tipe II dan mekanotransduksi kondrosit. Defisiensi kolagen ini menyebabkan peningkatan heterogenitas dan ketebalan rata-rata diameter kolagen fibril [36]. 
Kolagen tipe VI pada mencit berperan meningkatkan pembentukan jaringan tulang rawan dengan merangsang proliferasi kondrosit. Kekurangan kolagen ini dapat menyebabkan penurunan perkembangbiakan kondrosit yang menyebabkan kemungkinan cacat regenerasi dan percepatan osteoartritis. Selain itu, jika kolagen ini tidak ada, maka terjadi gangguan pada struktur tulang trabekuler dan mineralisasi yang berimplikasi pada disregulasi proses osifikasi endokondral. Kolagen tipe $\mathrm{VI}$ yang diisolasi dari sapi telah digunakan dengan PEG-CS 3D biomimetic hydrogel untuk pembentukan jaringan tulang rawan. Setelah 3 minggu, terbentuk jaringan tulang rawan yang kuat. Sehingga disimpulkan, kolagen ini dapat menjadi bahan biologis untuk prosedur implantasi autologus untuk rekayasa jaringan tulang rawan sebagai terapi cedera tulang rawan [42].

Kolagen tipe IX pada mencit berperan dalam stabilitas dan integritas matriks tulang rawan. Kolagen tipe IX adalah jembatan molekuler antara komponen matriks dan kondrosit. Tidak ada kolagen ini menyebabkan degradasi tulang rawan artikular. Hilangnya interaksi NC4 (domain kolagen tipe IV)-Fibronectin ini dapat mengganggu kemampuan kondrosit untuk merespon sinyal mekanis dan dapat mempengaruhi matriks tulang rawan menjadi terdegradasi seperti pada osteoarthritis [59].

Kolagen tipe $X$ pada mencit berperan penting dalam pembentukan tulang. Transaktivator Col10a1 adalah promotor hipertrofi kondrosit. Selain itu, kolagen ini juga merupakan target terapi untuk pertumbuhan tulang yang rendah seperti yang terlihat pada displasia skeletal. Jika kolagen ini berkurang akan menyebabkan penundaan hipertrofi kondrosit yang menyebabkan osteoarthritis [60].

Kolagen tipe XI diuji secara in vitro dan in vivo. ECM yang diisolasi dari babi mempromosikan proliferasi MSC (mesenchymal stem cells), produksi matriks tulang rawan, dan kematangan diferensiasi kondrogenik, dan menghambat diferensiasi hipertrofik kondrosit yang diturunkan dari MSC. Kolagen ini secara in vitro meningkatkan produksi dan menghambat degradasi matriks tulang rawan dalam pelet kondrosit artikular manusia dan eksplan tulang rawan artikular sapi [63]. Pada pengujian mencit, kekurangan kolagen ini menyebabkan chondrodysplasia yang terkait dengan kondrodistrofi [39].

Kolagen tipe XXVII diuji secara in vivo menggunakan mencit. Kolagen ini berperan dalam mengatur pericellular ECM of proliferative zone chondrocytes. Tanpa organisasi yang benar dari matriks ini, pola pembelahan sel dan kemampuan pengaturan kondrosit proliferatif akan terganggu. Hal ini akan mengakibatkan penurunan yang signifikan dalam kecepatan pertumbuhan tulang endokondral [102]. 


\section{Pencegahan Diastasis Rekti}

Diastasis rekti merupakan peningkatan lebar garis tengah perut yang secara eksklusif terdiri dari perluasan aponeurotik yang saling berhubungan dari otot perut anterolateral. Kadar kolagen tipe I dan tipe III yang rendah di garis tengah dinding perut mungkin memainkan peran kunci dalam perkembangan diastasis rekti. Kolagen berperan sebagai penyusun fasia abdominal dan aponeurosis, termasuk linea alba, sehingga kolagen memberikan dukungan dan ketahanan pada dinding abdominal terhadap tekanan intraabdomen. Kolagen tipe I memberikan ketahanan terhadap tegangan tarik abdominal. Sedangkan kolagen tipe III memberikan dukungan pada struktur abdominal. Tingkat kolagen tipe III juga meningkat selama tahap awal perbaikan luka [26].

\section{Perawatan Rambut}

Kolagen yang berperan dalam perawatan rambut adalah kolagen tipe $\mathrm{VI}$ dan XVII $[48,82]$. Kolagen tipe VI pada mencit berperan dalam regenerasi folikel rambut. Tingkat ekspresi kolagen dalam bulge stem cells lebih tinggi daripada di keratinosit yang terdiferensiasi menunjukkan bahwa kolagen $\mathrm{VI}$ dapat berkontribusi pada fungsi bulge dan perkembangan rambut. Kekurangan kolagen ini memperlambat siklus dan pertumbuhan rambut. Sehingga kolagen ini dapat menjadi terapi potensial untuk rambut rontok [48]. Kolagen tipe XVII pada mencit terlibat dalam pertumbuhan rambut. Kolagen ini sangat diekspresikan dalam HFSCs (hair follicle stem cells) di dalam folikel rambut dan diperlukan untuk pembaruan HFSCs sendiri. Apabila kekurangan kolagen ini maka dapat menyebabkan rambut beruban prematur dan rambut rontok [82].

\section{Stabilisasi Plak Aterosklerosis}

Kolagen tipe VIII pada mencit berfungsi untuk mengatur perkembangan fibrous cap di atheroma. Kolagen ini meningkatkan proliferasi dan migrasi SMC (smooth muscle cells) ke intima, mempengaruhi kelangsungan hidup sel, dan deposisi kolagen fibrillar tipe I setelah cedera vaskular yang merupakan mekanisme penting dalam melindungi plak aterosklerosis agar tidak pecah. Setelah cedera femoralis, tidak adanya kolagen ini menyebabkan apoptosis SMC meningkat dan migrasi ke intima menurun sehingga terjadi penurunan jumlah sel dan penurunan penebalan dinding pembuluh darah. Sedangkan tidak adanya kolagen ini menyebabkan perubahan besar dalam arsitektur plak termasuk penurunan SMC dan dan penipisan fibrous cap yang jelas. Sehingga disimpulkan bahwa kolagen ini dapat mendorong pertumbuhan fibrous cap yang kuat sehingga berperan penting dalam stabilisasi plak selama aterosklerosis [57].

Kolagen tipe XII berperan dalam menstabilkan struktur vaskular dan mencegah pembentukan lesi aterosklerosis. Kolagen ini biasanya ada di dinding aorta manusia. Namun, kolagen ini terdapat sedikit dalam intima plak aterosklerotik. Mekanisme kerjanya tidak pasti, namun diperkirakan karena domain von Willebrand factor A-like pada kolagen ini adalah mediator adhesif antara trombosit dan dinding pembuluh darah [39]. 


\section{Jantung}

Kolagen tipe IV berfungsi sebagai penyangga struktural untuk membentuk jaringan fibrillar lamina basal. Selain itu, kolagen ini memodulasi adhesi, proliferasi, migrasi, dan kelangsungan hidup ECs (sel endotel). Dalam penelitian ini, kolagen ini dapat berperan dalam meningkatkan endotelisasi vascular graft material. Sehingga disimpulkan, penggunaan kolagen ini merupakan teknik yang menjanjikan untuk memodifikasi vascular graft material untuk terapi penyakit arteri koroner [37].

Kolagen tipe VIII diuji secara in vivo pada mencit. Kolagen ini berperan dalam memfasilitasi interaksi ECM. Hilangnya kolagen ini dapat mengganggu integritas struktural miokardium yang menyebabkan dilatasi ventrikel kiri. Selain itu, kurangnya kolagen ini dapat menurunkan TGF- $\beta$ signaling yang akan mengurangi diferensiasi CFB (cardiac fibroblast) menjadi miofibroblas dan fibroblas, serta meningkatkan dilatasi ventrikel kiri dan mortalitas dini [58].

Kolagen tipe XII diuji secara in vivo pada ikan zebra. Kolagen ini berperan dalam regenerasi jantung. Kolagen ini dianggap memodulasi susunan matriks jantung. Selain itu, kolagen ini juga memodulasi fleksibilitas morfogenetiknya, terutama di bawah tekanan biofisik [68].

Kolagen tipe XIV pada tikus dapat berperan dalam pembentukan interstitium jantung dalam miokardium. Jika kolagen ini tidak ada, maka dapat meningkatkan kerentanan stress jantung. Kerentanan stress jantung ini biasanya menyebabkan kematian. Dan apabila mencit masih dapat hidup, maka beberapa jaringan ikat seperti pada tendon, kulit, ataupun miokardium menunjukkan kelainan struktural dan kelemahan fungsional [76].

\section{Perkembangan Mata}

Kolagen tipe $\mathrm{V}$ diuji secara in vivo dengan menggunakan mencit. Kolagen ini berperan dalam fibrillogenesis kornea. Fibrillogenesis adalah pembentukan fibril dimana dapat membentuk struktur mata. Jika tidak ada kolagen ini, maka menyebabkan disfungsional regulasi fibrillogenesis stroma kornea yang parah [40].

Kolagen tipe VIII diuji secara in vivo menggunakan mencit. Kolagen mungkin berperan dalam perkembangan mata. Namun mekanisme kerjanya tidak diketahui. Namun menurut penelitian, jika tidak ada kolagen ini menyebabkan disgenesis segmen anterior mata [39].

Kolagen tipe XII dan XIV mempengaruhi perkembangan dan fungsi endotel kornea dan fungsi kornea normal. Kolagen ini diuji secara in vivo menggunakan mencit. Mekanisme kerja kolagen ini belum diketahui. Namun, jika tidak ada kolagen ini, pematangan endotel kornea tertunda dan menjadi abnormal [64]. 
Kolagen tipe XVIII diuji secara in vivo menggunakan mencit. Kolagen ini berperan dalam pembentukan retina mata. Defisiensi kolagen ini dapat menyebabkan kelainan mata dimana adanya kerapuhan iris dan vaskularisasi retina yang abnormal [87]. Apabila kolagen ini tidak ada, maka dapat menyebabkan proteostais yang terganggu yang mungkin bertanggung jawab atas degenerasi RPE (retinal pigment epithelium). Hal ini akhirnya dapat menyebabkan kehilangan penglihatan [88].

\section{Pertumbuhan dan Perkembangan Gigi}

Kolagen tipe I berperan dalam regenerasi periodontal. Kolagen ini digunakan sebagai scaffolding material. Pada penelitian, dilakukan cangkok jaringan dari sapi (Bio-Oss Collagen) dengan membran kolagen Bio-Gide ke 14 pasien dengan defek infraboni bilateral atau kontralateral. Hasilnya adalah adanya peningkatan secara signifikan tinggi alveolar crest [27].

Kolagen tipe VII diuji secara in vivo menggunakan mencit. Kolagen ini berperan dalam pembentukan gigi. Kolagen tipe VII berperan dalam mengatur diferensiasi sel ameloblas dan memainkan peran penting dalam enamelisasi. Pada mencit yang kekurangan kolagen ini mengalami diferensiasi ameloblas yang terhambat mengakibatkan malformasi proses Tomes [56].

Kolagen tipe XVII diuji secara in vivo menggunakan mencit. Kolagen ini berperan dalam pembentukan gigi. Kolagen tipe XVII berperan penting dalam beberapa stabilitas hemidesmosom dan perlekatan mesenkim epitel. Kekurangan kolagen ini menunjukkan berkurangnya pigmentasi kuning, deposisi besi berkurang, kalsifikasi tertunda, dan prisma email yang tidak teratur. Kekurangan kolagen ini menunjukkan ameloblas yang berdiferensiasi buruk [56].

Kolagen tipe XVIII diuji dari gigi satu wanita dan satu pria normal. Kolagen ini mungkin berperan dalam perkembangan gigi. Namun, mekanisme kerja kolagen ini tidak diketahui. Dalam penelitian, kolagen ini sangat diekspresikan dalam DPSCs (dental pulp stem cells) [89].

\section{Perkembangan Tendon}

Kolagen yang berperan dalam regulasi fibrillogenesis selama perkembangan tendon adalah kolagen tipe I, III, V, VI, XI, XII, dan XIV. Apabila tidak ada kolagen tersebut, maka menyebabkan regulasi disfungsional fibrillogenesis tendon sehingga terjadi penurunan kekuatan tarik dan kekakuan tendon $[29,41,45,67,76]$. Selain itu, kolagen tipe I dan III dapat menyembuhkan ruptur rotator cuff tendon [29]. 


\section{Perkembangan Saraf}

Kolagen tipe VI diuji secara in vivo menggunakan mencit. Kolagen ini berperan dalam regulator untuk regenerasi saraf perifer dengan memodulasi fungsi makrofag. Apabila kekurangan kolagen ini dapat menyebabkan penundaan regenerasi saraf perifer [49]. Kolagen ini juga berperan secara protektif di SSP selama penuaan fisiologis. Kurangnya kolagen ini menyebabkan apoptosis spontan dan autofagi yang rusak pada sel saraf sehingga dapat menurunkan memori [50].

Kolagen tipe XI diuji secara in vivo menggunakan mencit. Kolagen ini mungkin berperan dalam homeostasis annulus fibrosus. Kolagen ini tidak diketahui secara pasti mekanisme kerjanya. Namun, kolagen ini mungkin berperan sebagai penyebar informasi mekanosensori ke sel annulus fibrosus yang mengatur homeostasis annulus fibrosus.

Kolagen tipe XIII diuji secara in vivo menggunakan mencit. Kolagen ini berperan dalam menjaga integritas postsinaptik, sinaptik, dan presinaptik. Selain itu, kolagen ini juga mempertahankan kapasitas fungsional dari sinaps neuromuskular. Jika kolagen tidak ada, maka menyebabkan atrofi otot [70].

Kolagen tipe XV diuji secara in vivo menggunakan mencit. Kolagen ini mungkin berperan dalam mielinisasi saraf perifer. Apabila kolagen ini tidak ada, maka dapat menyebabkan mielinisasi saraf perifer yang rusak. Selain mielinisasi saraf perifer, kolagen ini juga berperan dalam motor axon pathfinding karena diekspresikan oleh sel adaxial setelah aktivasi Hedgehog dan unplugged/MuSK signaling sehingga berperan dalam perkembangan neuromuskular. Kurangnya kolagen ini dapat menyebabkan atrofi otot dan hewan menjadi sulit berenang [80].

Kolagen tipe XVI diuji secara in vivo menggunakan mencit. Kolagen ini berperan dalam proses regenerasi saraf. Mekanisme kerja kolagen ini tidak diketahui. Namun, ekspresi kolagen ini meningkat di sekitar badan sel saraf sebagai respons terhadap cedera saraf [39].

Kolagen tipe XIX diuji secara in vivo menggunakan tikus. Kolagen ini mungkin diperlukan untuk perkembangan otak. Mekanisme kerja kolagen ini tidak diketahui. Namun, kekurangan kolagen ini dapat menghambat perkembangan otak. Sementara jika kolagen ini hilang total dapat menyebabkan kejang dan perubahan perilaku yang berkaitan dengan skizofrenia [91]. 


\section{Pertumbuhan dan Homeostasis Otot}

Kolagen tipe $\mathrm{VI}$ diuji menggunakan mencit meregulasi satellite cell self-renewal dan regenerasi otot. Kekurangan kolagen ini dapat menyebabkan regenerasi otot terganggu dan kemampuan satellite cell self-renewal berkurang setelah cedera. Dan apabila kolagen ini tidak ada menyebabkan penurunan kekakuan otot yang signifikan yang menganggu aktivitas satelite cell dalam perbaikan otot [13]. Selain meregulasi satellite cell self-renewal dan regenerasi otot, kolagen ini juga berperan dalam homeostasis otot. Apabila kolagen ini tidak ada pada mencit akan menyebabkan penurunan fluks autofagi yang menyebabkan apoptosis dan degenerasi serat otot [46].

Kolagen tipe XII diuji secara in vivo menggunakan mencit berperan dalam melindungi integritas otot dengan mengatur fibril kolagen [65]. Hilangnya kolagen ini menyebabkan kelemahan otot. Selain kelemahan otot, apabila kolagen ini hilang juga dapat menyebabkan perubahan komposisi jenis serat di otot, serta perubahan elastisitas otot [66].

Kolagen tipe $\mathrm{XV}$ diuji secara in vivo menggunakan mencit berperan dalam menjaga permeabilitas kapiler pada otot lurik. Perubahan struktur atau integritas kolagen ini menyebabkan peningkatan kerapuhan dan permeabilitas vaskular, dan secara substansial berkontribusi pada beragam fungsi pembuluh darah [81]. Kekurangan kolagen ini dapat menyebabkan peningkatan permeabilitas vaskular dan dapat menyebabkan skeletal myopathy [79,81]. Sama halnya dengan kolagen tipe XV, kolagen tipe XVIII juga berperan dalam menjaga permeabilitas kapiler pada otot lurik dan apabila kekurangan kolagen ini dapat menyebabkan peningkatan aliran darah dan permeabilitas vaskular [81].

Kolagen tipe XIX diuji secara in vivo menggunakan mencit. Kolagen ini berperan dalam fisiologi dan diferensiasi otot. Mekanisme kerja kolagen ini tidak diketahui pasti. Namun, apabila kolagen ini tidak ada, maka dapat menyebabkan gangguan konversi sel otot polos ke rangka di segmen perut esofagus [39].

Kolagen tipe XXII diuji secara in vivo menggunakan ikan zebra. Kolagen ini mungkin berperan dalam menjaga perlekatan otot. Mekanisme kerja kolagen ini tidak diketahui pasti. Namun, apabila kekurangan kolagen ini dapat menyebabkan distrofi otot karena destabilisasi myosepta [95].

Kolagen tipe XXV diuji secara in vivo menggunakan mencit. Kolagen ini berperan dalam perkembangan otot rangka. Hal ini terbukti karena kolagen ini terlibat dalam fusi mioblast menjadi miotube selama miogenesis. Miogenesis merupakan pembentukan jaringan otot rangka [99]. 


\section{Pertumbuhan dan Homeostasis Kulit}

Kolagen tipe I yang diisolasi dari babi berfungsi dalam penyembuhan luka kronis. Matriks kolagen ini digunakan sebagai sacrificial surface untuk matriks metaloproteinase dan elastase yang ada pada luka kronis sehingga melindungi pengendapan kolagen jaringan. Karena matriks kolagen ini maka struktur matriks kolagen asli dapat dipertahankan. Matriks kolagen asli yang dipertahankan akan mendukung penyembuhan dan secara efektif mengatasi ketidakseimbangan protease yang terlihat pada luka kronis dan mendukung pembentukan jaringan granulasi dan epitelisasi [28].

Kolagen tipe III juga berperan dalam penyembuhan luka. Mekanisme kerja kolagen ini tidak diketahui pasti. Namun, kolagen ini berkurang seiring bertambahnya usia yang mengubah ketegangan, elastisitas, dan penyembuhan kulit [34]. Kekurangan kolagen ini pada tikus menyebabkan adanya jaringan parut yang lebih banyak daripada tikus yang tidak kekurangan kolagen ini [33].

Kolagen tipe IV diuji secara in vivo menggunakan mencit. Kolagen ini berperan dalam regenerasi jaringan. Karena berperan dalam regenerasi jaringan maka kolagen ini juga mungkin berperan dalam penyembuhan luka. Namun, mekanisme kerja kolagen ini tidak diketahui pasti [39].

Kolagen tipe VI diuji secara in vivo menggunakan mencit. Kolagen ini berperan dalam pembentukan karakteristik kulit. Apabila kolagen ini tidak ada akan menyebabkan penurunan kekuatan tarik kulit dan berubahnya fibril kolagen dan arsitektur membran basal [51]. Selain pembentukan karakteristik kulit, kolagen ini mungkin berperan penting dalam penyembuhan luka dan regenerasi jaringan karena kolagen ini merupakan pengatur kunci dari perakitan matriks dermal, komposisi, dan perilaku fibroblast [43].

Kolagen tipe VII yang dibuat secara sintetik (human recombinant $r C 7$ ) diuji secara in vivo menggunakan mencit. Kolagen ini berperan dalam perlekatan epidermal dan dermal. Kolagen ini dapat mencegah pembentukan lepuh dan erosi kulit [54]. Secara topikal, kolagen ini dapat menyembuhkan luka dan mempercepat penutupan luka dengan meningkatkan re-epitelisasi. Sehingga berpotensi untuk terapi pasien RDEB (recessive dystrophic epidermolysis bullosa) dengan luka kulit kronis [55].

Kolagen tipe XII diuji secara in vivo menggunakan mencit. Kolagen ini berperan dalam homeostasis dan perbaikan kulit. Mekanisme kerja kolagen ini tidak diketahui pasti. Namun, apabila kolagen ini berkurang akan menyebabkan penyembuhan luka yang tertunda [39].

Kolagen tipe XIV diuji secara in vivo menggunakan mencit. Kolagen ini berperan dalam fibrillogenesis kulit. Fibrillogenesis kulit akan membentuk struktur dan fleksibilitas kulit. Apabila kolagen ini tidak ada terjadi disfungsional fibrillogenesis pada kulit [76]. 
Kolagen tipe XVII diuji dari sampel 43 pasien dengan JEB (junctional epidermolysis bullosa). Kolagen ini berperan dalam meningkatkan stabilitas kulit. Kolagen ini berperan sebagai reseptor permukaan sel dan sebagai komponen matriks. Kolagen ini mempertahankan adhesi keratinosit basal ke membran basal. Apabila kolagen ini berkurang dapat menyebabkan berkurangnya adhesi dermal-epidermal dan lepuh kulit [85].

Kolagen tipe XXIII diuji secara in vivo menggunakan mencit. Pada kulit, kolagen ini terlokalisasi ke permukaan sel keratinosit di semua lapisan epidermis. Kolagen ini berperan dalam penyembuhan luka. Mekanisme kerjanya adalah kolagen ini berinteraksi dengan integrin $\alpha_{2} \beta_{1}$ yang menginduksi adhesi dan penyebaran keratinosit yang mempunyai fungsi dalam penyembuhan luka [97].

\section{Pertumbuhan dan Homeostasis Tulang}

Kolagen tipe III diuji secara in vivo menggunakan mencit. Kolagen ini berperan dalam pembentukan osteoblast yang terlibat dalam pembentukan tulang. Namun, mekanisme kerjanya tidak diketahui pasti. Jika kolagen ini menurun maka secara signifikan menurunkan massa tulang trabekular [35].

Kolagen tipe VI diuji secara in vivo menggunakan mencit. Kolagen ini berperan dalam perakitan dan pematangan tulang. Kurangnya kolagen ini dapat menyebabkan kelainan tulang. Jika tidak ada kolagen ini dapat menyebabkan degenerasi tulang rawan dan menyebabkan kelainan muskuloskeletal pada lutut [47].

Kolagen tipe $X$ diuji secara in vivo menggunakan mencit. Kolagen ini berperan dalam pembentukan tulang. Jika tidak ada kolagen ini dapat menyebabkan tulang trabekular abnormal, coxa vara, tulang rawan artikular abnormal [39]. Kolagen ini juga berperan dalam osifikasi endokondral dimana kemungkinan kolagen ini dapat menyembuhkan fraktur tulang [61].

Kolagen tipe XII diuji secara in vivo menggunakan mencit. Kolagen ini berperan dalam melindungi integritas tulang dengan mengatur fibril kolagen. Namun, tidak diketahui secara pasti mekanisme kerjanya. Apabila terjadi mutasi kolagen ini dapat menyebabkan kelainan tulang [65].

Kolagen tipe XIII diuji secara in vivo menggunakan mencit. Kolagen ini berperan dalam adhesi matriks sel. Kolagen ini juga berperan dalam pengembangan, diferensiasi, dan pematangan jaringan muskuloskeletal serta menjaga integritas jaringan. Oleh karena itu, disimpulkan bahwa kolagen ini dapat berperan dalam regulasi homeostasis tulang [71].

Kolagen tipe $\mathrm{XV}$ diuji secara in vitro. Kolagen ini mungkin berperan dalam proses osteogenik sebagai tahap pembentukan tulang. Dalam proses osteogenik, kolagen ini berperan dalam merespons sinyal yang mendukung lingkungan osteoblas yang baru lahir. Kolagen ini juga mungkin dapat memperbaiki kerusakan tulang [77]. 
Kolagen tipe XXIV diuji secara in vitro. Kolagen ini berperan dalam diferensiasi osteoblas dan mineralisasi. Kolagen ini terikat dengan rantai integrin $\beta 3$ yang memediasi aktivasi TGF- $\beta$. Protein Smad yang merupakan komponen dari jalur persinyalan TGF- $\beta$ mengatur diferensiasi osteoblas [98].

\section{Pematangan Neuromuscular Junction}

Kolagen tipe XIII memiliki domain intraseluler terminal- $\mathrm{N}$, domain transmembran hidrofobik, dan domain C-terminal ekstraseluler yang besar yang berinteraksi secara in vitro dengan ECM seperti fibronektin, reseptor seluler seperti subunit integrin a1 dan komponen BM perlecan dan nidogen-2. Tiga molekul terakhir adalah komponen NMJ sehingga kolagen mungkin berperan dalam menstabilkan dan pematangan NMJ (neuromuscular junction). Apabila kolagen ini tidak ada pada mencit maka menyebabkan gangguan diferensiasi dan fungsi NMJ [69].

Kolagen tipe XXV mengatur pematangan NMJ serta regenerasinya setelah cedera sehingga kolagen ini mungkin terlibat dalam adhesi sel selama perkembangan neuromuskular. Untuk mencapai perkembangan neuromuskular yang akurat, akson motorik perlu menghentikan pemanjangan pada saat dan tempat yang tepat, yaitu di daerah endplate. Gangguan pembentukan NMJ menyebabkan pertumbuhan berlebih atau percabangan akson motorik yang berlebihan sehingga disimpulkan kolagen ini berperan sebagai faktor pendorong pertumbuhan akson intramuskular [100].

\section{Lainnya}

Kolagen tipe IV diuji secara in vivo menggunakan tikus. Kolagen ini mungkin berperan dalam pencegahan fibrosis hati. Hal ini karena CO4-MMP (fragmen kolagen IV terdegradasi) meningkat pada tikus fibrosis hati. Namun, mekanisme kerja kolagen ini tidak diketahui pasti [38].

Kolagen tipe XIV diuji secara in vitro. Kolagen ini berpotensi untuk terapi kalsifikasi vaskular. Hal ini karena kolagen ini dapat menghambat aktivasi Ca/P-induced ERK1/2, $N F-K B$ signaling, dan Wnt-signaling yang terlibat dalam kalsifikasi vaskular yang merupakan salah satu faktor risiko infark miokardial. Selain itu, kolagen ini juga menganggu transdiferensiasi osteochondrocytic dari VSMC (vascular smooth muscle cells) dimana transdiferensiasi osteochondrocytic terlibat dalam proses perkembangan kalsifikasi arteri [74].

Kolagen tipe XVII diuji secara in vivo menggunakan mencit. Kolagen ini mungkin memiliki fungsi dalam menempelkan foot processes podosit pada membran basal glomerulus. Ini mungkin berkontribusi pada pematangan podosit dan mungkin berperan dalam filtrasi glomerulus. Defisiensi kolagen ini menyebabkan penipisan foot processes podosit [84]. 
Kolagen tipe XVIII diuji secara in vivo menggunakan mencit. Kolagen ini berperan dalam regenerasi hati. Hal ini karena kolagen ini mengikat $\alpha 1 \beta 1$ integrin. Interaksi tersebut kemudian akan menginduksi sinyal hepatocyte survival melalui integrin-linked kinase (ILK) sebagai respons cedera sehingga dapat melindungi hepatosit dari kerusakan yang lebih cepat [86].

Kolagen tipe XXI berfungsi sebagai jembatan molekuler dalam matriks ekstraselular. Kolagen ini juga mungkin berperan dalam perakitan pembuluh darah. Namun, mekanisme kerjanya tidak diketahui pasti. Hanya diketahui bahwa ekspresi kolagen ini diatur oleh platelet-derived growth factor yang menginduksi proliferasi dan migrasi sel otot polos [39].

Kolagen tipe XXII diuji secara in vivo menggunakan ikan zebra dan mencit berperan dalam integritas struktural jaringan ikat. Selain itu, kolagen ini juga menjaga integritas vaskular karena kolagen ini merupakan komponen utama ECM di dalam dinding pembuluh darah. Dinding pembuluh darah mengandung membran basal subendotelial, intima, adventitia dan lapisan matriks interstisial yang masing-masing mengandung kolagen yang sangat penting untuk stabilitas vaskular. Apabila tidak ada kolagen ini, maka dapat terjadi pendarahan di daerah mata serta terjadi dilatasi pembuluh darah [96].

Kolagen tipe XXVIII termasuk ECM yang berfungsi sebagai pengatur utama morfogenesis dan perbaikan jaringan. Kolagen ini diuji secara in vivo menggunakan mencit cedera paru-paru. Kolagen ini mungkin membantu perbaikan cedera jaringan atau fibrosis. Namun tidak diketahui pasti mekanisme kerjanya [103].

Kolagen tipe XXIX terdapat pada kulit. Kolagen ini diuji secara in vitro menggunakan sampel dari anjing atopik dermatitis. Kolagen ini mungkin berperan dalam organisasi arsitektur jaringan dan adhesi sel. Dalam penelitian, kolagen ini terdeteksi di anjing yang atopik dermatitis sehingga mungkin berperan dalam perbaikan kulit [105].

\section{Kesimpulan}

Kolagen memiliki berbagai aktivitas yaitu antioksidan, antiinflamasi, antidiabetes, antikanker, antimikroba, antiaging, kondroprotektif, pencegahan diastasis rekti, perawatan rambut, stabilisasi plak aterosklerosis, terapi jantung, pertumbuhan dan homeostasis mata, gigi, tendon, saraf, otot, kulit, dan tulang, pematangan neuromuscular junction (NMJ), dan lainnya. Selain itu, kolagen ini juga mempunyai karakteristik fisikokimia yang baik sehingga dapat diterima oleh tubuh dengan baik. Oleh karena itu, kolagen dapat dijadikan sediaan farmasi sebagai suplemen, kosmetik, ataupun scaffolding material untuk kesehatan. 


\section{Daftar Pustaka}

1. Sinthusamran S, Benjakul S, Kishimura H. Comparative study on molecular characteristics of acid soluble collagens from skin and swim bladder of seabass (Lates calcarifer). Food Chemistry [Internet]. 2013;138(4):2435-41. Available from: http://dx.doi.org/10.1016/j.foodchem. 2012.11.136

2. Arseni L, Lombardi A, Orioli D. From structure to phenotype: impact of collagen alterations on human health. International Journal of Molecular Sciences. 2018;19(5).

3. Kumbar SG, Laurencin C, Deng M, editors. Natural and Synthetic Biomedical Polymers [Internet]. USA: Elsevier Science; 2014. Available from: https://books.google.co.id/books?id=QX58AQAAQBAJ

4. Fidler AL, Boudko SP, Rokas A, Hudson BG. The triple helix of collagens - an ancient protein structure that enabled animal multicellularity and tissue evolution. Journal of Cell Science. 2018;131(7).

5. Liu D, Liang L, Regenstein JM, Zhou P. Extraction and characterisation of pepsinsolubilised collagen from fins, scales, skins, bones and swim bladders of bighead carp (Hypophthalmichthys nobilis). Food Chemistry [Internet]. 2012;133(4):1441-8. Available from: http://dx.doi.org/10.1016/j.foodchem.2012.02.032

6. Rodríguez MIA, Barroso LGR, Sánchez ML. Collagen: a review on its sources and potential cosmetic applications. Journal of Cosmetic Dermatology. 2018;17(1):20-6.

7. Park S, Kang S, Lee WJ. Menopause, ultraviolet exposure, and low water intake potentially interact with the genetic variants related to collagen metabolism involved in skin wrinkle risk in middle-aged women. International Journal of Environmental Research and Public Health. 2021;18(4):1-12.

8. Overbeek SA, Braber S, Koelink PJ, Henricks PAJ, Mortaz E, LoTam Loi AT, et al. Cigarette smoke-induced collagen destruction; key to chronic neutrophilic airway inflammation? PLoS ONE. 2013;8(1).

9. Snedeker JG, Gautieri A. The role of collagen crosslinks in ageing and diabetes - the good, the bad, and the ugly. Muscles, Ligaments and Tendons Journal. 2014;4(3):303-8.

10. Cheng Q, Zhang X, Jiang J, Zhao G, Wang $Y, X u$ Y, et al. Postmenopausal iron overload exacerbated bone loss by promoting the degradation of type i collagen. BioMed Research International. 2017;2017.

11.Zdzieblik D, Oesser S, Baumstark MW, Gollhofer A, König D. Collagen peptide supplementation in combination with resistance training improves body composition and increases muscle strength in elderly sarcopenic men: a randomised controlled trial. British Journal of Nutrition. 2015;114(8):1237-45.

12. Hosseininia S, Lindberg LR, Dahlberg LE. Cartilage collagen damage in hip osteoarthritis similar to that seen in knee osteoarthritis; a case-control study of relationship between collagen, glycosaminoglycan and cartilage swelling. BMC Musculoskeletal Disorders. 2013;14.

13. Urciuolo A, Quarta M, Morbidoni V, Gattazzo F, Molon S, Grumati P, et al. Collagen VI regulates satellite cell self-renewal and muscle regeneration. Nature Communications [Internet]. 2013;4:1-13. Available from: http://dx.doi.org/10.1038/ncomms2964 
14. Borumand M, Sibilla S. Daily consumption of the collagen supplement pure gold collagen ${ }^{\circledR}$ reduces visible signs of aging. Clinical Interventions in Aging. 2014;9:1747-58.

15. Chi C-F, Cao Z-H, Wang B, Hu F-Y, Li Z-R, Zhang B. Antioxidant and functional properties of collagen hydrolysates from spanish mackerel skin as influenced by average molecular weight. Molecules. 2014;19(8):11211-30.

16. Albu MG, Ferdes M, Kaya DA, Ghica M v., Titorencu I, Popa L, et al. Collagen wound dressings with anti-inflammatory activity. Molecular Crystals and Liquid Crystals. 2012;555:271-9.

17. Petäistö T, Vicente D, Mäkelä KA, Finnilä MA, Miinalainen I, Koivunen J, et al. Lack of collagen XVIII leads to lipodystrophy and perturbs hepatic glucose and lipid homeostasis. Journal of Physiology. 2020;598(16):3373-93.

18. Wu B, Chen $\mathrm{H}$, Shen J, Ye M. Cost-effectiveness of adding rh-endostatin to first-line chemotherapy in patients with advanced non-small-cell lung cancer in china. Clinical Therapeutics. 2011;33(10):1446-55.

19. Ferreira AM, Gentile P, Chiono V, Ciardelli G. Collagen for bone tissue regeneration. Acta Biomaterialia [Internet]. 2012;8(9):3191-200. Available from: http://dx.doi.org/10.1016/j.actbio.2012.06.014

20. Hashim P, Mohd Ridzwan MS, Bakar J, Mat Hashim D. Collagen in food and beverage industries. International Food Research Journal. 2015;22(1):1-8.

21. Lin K, Zhang D, Macedo MH, Cui W, Sarmento B, Shen G. Advanced collagenbased biomaterials for regenerative biomedicine. Advanced Functional Materials. 2019;29(3):1-16.

22. Subhan F, Hussain Z, Tauseef I, Shehzad A, Wahid F. A review on recent advances and applications of fish collagen. Critical Reviews in Food Science and Nutrition [Internet]. 2020;61(6):1-11. Available from: https://doi.org/10.1080/10408398.2020.1751585

23. Domb AJ, Kumar N, Ezra A, editors. Biodegradable polymers in clinical use and clinical development [Internet]. USA: Wiley; 2011. Available from: https://books.google.co.id/books?id=LUOQu6\%5C_kLZQC

24. Dar QA, Schott EM, Catheline SE, Maynard RD, Liu Z, Kamal F, et al. Daily oral consumption of hydrolyzed type 1 collagen is chondroprotective and antiinflammatory in murine posttraumatic osteoarthritis. PLoS ONE. 2017;12(4):124.

25. Nakchum L, Kim SM. Preparation of squid skin collagen hydrolysate as an antihyaluronidase, antityrosinase, and antioxidant agent. Preparative Biochemistry and Biotechnology. 2016;46(2):123-30.

26. Blotta RM, Costa S dos S, Trindade EN, Meurer L, Maciel-Trindade MR. Collagen I and III in women with diastasis recti. Clinics. 2018;73(5):1-5.

27. Palachur D, Rao KVP, Murthy KR v., Kishore DT, Reddy MN, Bhupathi A. A comparative evaluation of bovine-derived xenograft (Bio-Oss Collagen) and type $\mathrm{i}$ collagen membrane (Bio-Gide) with bovine-derived xenograft (Bio-Oss Collagen) and fibrin fibronectin sealing system (TISSEEL) in the treatment of intrabony defects: A clini. Journal of Indian Society of Periodontology. 2014;18(3):336-43.

28. Oropallo AR. Use of native type i collagen matrix plus polyhexamethylene biguanide for chronic wound treatment. Plastic and Reconstructive Surgery - Global Open. 2019;7(1):1-6. 
29. Shirachi I, Gotoh M, Mitsui Y, Yamada T, Nakama K, Kojima K, et al. Collagen production at the edge of ruptured rotator cuff tendon is correlated with postoperative cuff integrity. Arthroscopy - Journal of Arthroscopic and Related Surgery [Internet]. 2011;27(9):1173-9. Available from: http://dx.doi.org/10.1016/j.arthro.2011.03.078

30. Bakilan F, Armagan O, Ozgen M, Tascioglu F, Bolluk O, Alatas O. Effects of native type II collagen treatment on knee osteoarthritis: A randomized controlled trial. Eurasian Journal of Medicine. 2016;48(2):95-101.

31. Tamaddon M, Burrows M, Ferreira SA, Dazzi F, Apperley JF, Bradshaw A, et al. Monomeric, porous type II collagen scaffolds promote chondrogenic differentiation of human bone marrow mesenchymal stem cells in vitro. Scientific Reports [Internet]. 2017;7:1-10. Available from: http://dx.doi.org/10.1038/srep43519

32. Dai M, Sui B, Xue Y, Liu X, Sun J. Cartilage repair in degenerative osteoarthritis mediated by squid type II collagen via immunomodulating activation of M2 macrophages, inhibiting apoptosis and hypertrophy of chondrocytes. Biomaterials [Internet]. 2018;180:91-103.

Available

from: https://doi.org/10.1016/j.biomaterials.2018.07.011

33. Volk SW, Wang Y, Mauldin EA, Liechty KW, Adams SL. Diminished type III collagen promotes myofibroblast differentiation and increases scar deposition in cutaneous wound healing. Cells Tissues Organs. 2011;194(1):25-37.

34. Cheng W, Yan-Hua R, Fang-Gang N, Guo-An Z. The content and ratio of type I and III collagen in skin differ with age and injury. African Journal of Biotechnology. 2011;10(13):2524-9.

35. Volk SW, Shah SR, Cohen AJ, Wang Y, Brisson BK, Vogel LK, et al. Type III collagen regulates osteoblastogenesis and the quantity of trabecular bone. Calcified Tissue International. 2014;94(6):621-31.

36. Wang C, Brisson BK, Terajima M, Li Q, Hoxha K, Han B, et al. Type III collagen is a key regulator of the collagen fibrillar structure and biomechanics of articular cartilage and meniscus. Matrix Biology [Internet]. 2020;85-86:47-67. Available from: https://doi.org/10.1016/j.matbio.2019.10.001

37. Heo Y, Shin YM, Lee Y bin, Lim YM, Shin H. Effect of immobilized collagen type IV on biological properties of endothelial cells for the enhanced endothelialization of synthetic vascular graft materials. Colloids and Surfaces B: Biointerfaces [Internet]. 2015;134:196-203. Available from: http://dx.doi.org/10.1016/j.colsurfb.2015.07.003

38. Veidal SS, Karsdal MA, Nawrocki A, Larsen MR, Dai Y, Zheng Q, et al. Assessment of proteolytic degradation of the basement membrane: A fragment of type IV collagen as a biochemical marker for liver fibrosis. Fibrogenesis and Tissue Repair. 2011;4(1):1-11.

39. Karsdal M, editor. Biochemistry of Collagens, Laminins and Elastin: Structure, Function and Biomarkers [Internet]. Belanda: Elsevier Science; 2016. Available from: https://books.google.co.id/books?id=BXqLCwAAQBAJ

40. Sun M, Chen S, Adams SM, Florer JB, Liu H, Kao WWY, et al. Collagen V is a dominant regulator of collagen fibrillogenesis: Dysfunctional regulation of structure and function in a corneal-stroma-specific Col5a1-null mouse model. Journal of Cell Science. 2011;124(23):4096-105. 
41. Wenstrup RJ, Smith SM, Florer JB, Zhang G, Beason DP, Seegmiller RE, et al. Regulation of collagen fibril nucleation and initial fibril assembly involves coordinate interactions with collagens $\mathrm{V}$ and $\mathrm{XI}$ in developing tendon. Journal of Biological Chemistry. 2011;286(23):20455-65.

42. Smeriglio P, Dhulipala L, Lai JH, Goodman SB, Dragoo JL, Smith RL, et al. Collagen VI enhances cartilage tissue generation by stimulating chondrocyte proliferation. Tissue Engineering Part A [Internet]. 2015;21(3-4):1-41. Available from: http://www.statistik.at/KDBWeb/kdb.do?FAM=WISS\&\&NAV=EN\&\&KDBtoken=null

43. Theocharidis G, Drymoussi Z, Kao AP, Barber AH, Lee DA, Braun KM, et al. Type VI collagen regulates dermal matrix assembly and fibroblast motility. Journal of Investigative Dermatology [Internet]. 2016;136(1):74-83. Available from: http://dx.doi.org/10.1038/jid.2015.352

44. Llacua LA, Hoek A, de Haan BJ, de Vos P. Collagen type VI interaction improves human islet survival in immunoisolating microcapsules for treatment of diabetes. Islets [Internet]. 2018;10(2):60-8. Available from: https://doi.org/10.1080/19382014.2017.1420449

45. Izu Y, Ansorge HL, Zhang G, Soslowsky LJ, Bonaldo P, Chu ML, et al. Dysfunctional tendon collagen fibrillogenesis in collagen VI null mice. Matrix Biology [Internet]. 2011;30(1):53-61. Available from: http://dx.doi.org/10.1016/j.matbio.2010.10.001

46. Grumati $P$, Coletto L, Schiavinato A, Castagnaro S, Bertaggia E, Sandri M, et al. Physical exercise stimulates autophagy in normal skeletal muscles but is detrimental for collagen VI-deficient muscles. Autophagy. 2011;7(12):1415-23.

47. Christensen SE, Coles JM, Zelenski NA, Furman BD, Leddy HA, Zauscher S, et al. Altered trabecular bone structure and delayed cartilage degeneration in the knees of collagen vi null mice. PLoS ONE. 2012;7(3).

48. Chen P, Cescon M, Bonaldo P. Lack of collagen VI promotes wound-induced hair growth. Journal of Investigative Dermatology [Internet]. 2015;135(10):2358-67. Available from: http://dx.doi.org/10.1038/jid.2015.187

49. Chen P, Cescon M, Zuccolotto G, Nobbio L, Colombelli C, Filaferro M, et al. Collagen VI regulates peripheral nerve regeneration by modulating macrophage recruitment and polarization. Acta Neuropathologica. 2015;129(1):97-113.

50. Cescon M, Chen P, Castagnaro S, Gregorio I, Bonaldo P. Lack of collagen VI promotes neurodegeneration by impairing autophagy and inducing apoptosis during aging. Aging. 2016;8(5):1083-101.

51. Lettmann S, Bloch W, Maaß T, Niehoff A, Schulz JN, Eckes B, et al. Col6a1 null mice as a model to study skin phenotypes in patients with collagen $\mathrm{VI}$ related myopathies: expression of classical and novel collagen VI variants during wound healing. PLoS ONE. 2014;9(8):3-11.

52. Abdillahi SM, Maaß T, Kasetty G, Strömstedt AA, Baumgarten M, Tati R, et al. Collagen VI contains multiple host defense peptides with potent in vivo activity. The Journal of Immunology. 2018;201(3):1007-20.

53. Jung JP, Lin WH, Riddle MJ, Tolar J, Ogle BM. A 3D in vitro model of the dermoepidermal junction amenable to mechanical testing. Journal of Biomedical Materials Research - Part A. 2018;106(12):3231-8. 
54. Woodley DT, Wang X, Amir M, Hwang B, Remington J, Hou Y, et al. Intravenously injected recombinant human type VII collagen homes to skin wounds and restores skin integrity of dystrophic epidermolysis bullosa. Journal of Investigative Dermatology. 2013;133(7):1910-3.

55. Wang X, Ghasri P, Amir M, Hwang B, Hou Y, Khilili M, et al. Topical application of recombinant type VII collagen incorporates into the dermal-epidermal junction and promotes wound closure. Molecular Therapy. 2013;21(7):1335-44.

56. Umemoto H, Akiyama M, Domon T, Nomura T, Shinkuma S, Ito K, et al. Type VII collagen deficiency causes defective tooth enamel formation due to poor differentiation of ameloblasts. American Journal of Pathology. 2012;181(5):1659-71.

57. Lopes J, Adiguzel E, Gu S, Liu SL, Hou G, Heximer S, et al. Type VIII collagen mediates vessel wall remodeling after arterial injury and fibrous cap formation in atherosclerosis. American Journal of Pathology [Internet]. 2013;182(6):2241-53. Available from: http://dx.doi.org/10.1016/j.ajpath.2013.02.011

58. Skrbic B, Engebretsen KVT, Strand ME, Lunde IG, Herum KM, Marstein HS, et al. Lack of collagen VIII reduces fibrosis and promotes early mortality and cardiac dilatation in pressure overload in mice. Cardiovascular Research. 2015;106(1):3242.

59. Parsons P, Gilbert SJ, Vaughan-Thomas A, Sorrell DA, Notman R, Bishop M, et al. Type IX collagen interacts with fibronectin providing an important molecular bridge in articular cartilage. Journal of Biological Chemistry. 2011;286(40):34986-97.

60. Gu J, Lu Y, Li F, Qiao L, Wang Q, Li N, et al. Identification and characterization of the novel Col10a1 regulatory mechanism during chondrocyte hypertrophic differentiation. Cell Death and Disease. 2014;5(10):1-11.

61. Coghlan RF, Oberdorf JA, Sienko S, Aiona MD, Boston BA, Connelly KJ, et al. A degradation fragment of type $X$ collagen is a real-time marker for bone growth velocity. Science Translational Medicine. 2017;9(419).

62. Smith SM, Melrose J. Type XI collagen-perlecan-HS interactions stabilise the pericellular matrix of annulus fibrosus cells and chondrocytes providing matrix stabilisation and homeostasis. Journal of Molecular Histology [Internet]. 2019;50(3):285-94. Available from: https://doi.org/10.1007/s10735-019-09823-1

63. Li A, Wei Y, Hung C, Vunjak-Novakovic G. Chondrogenic properties of collagen type $\mathrm{XI}$, a component of cartilage extracellular matrix. Biomaterials [Internet]. 2018;173:47-57. Available from: https://doi.org/10.1016/j.biomaterials.2018.05.004

64. Hemmavanh C, Koch M, Birk DE, Espana EM. Abnormal corneal endothelial maturation in collagen XII and XIV Null mice. Investigative Ophthalmology and Visual Science. 2013;54(5):3297-308.

65. Chiquet M, Birk DE, Bönnemann CG, Koch M. Collagen XII: protecting bone and muscle integrity by organizing collagen fibrils. International Journal of Biochemistry and Cell Biology [Internet]. 2014;53:51-4. Available from: http://dx.doi.org/10.1016/j.biocel.2014.04.020

66. Zou Y, Zwolanek D, Izu Y, Gandhy S, Schreiber G, Brockmann K, et al. Recessive and dominant mutations in COL12A1 cause a novel EDS/myopathy overlap syndrome in humans and mice. Human Molecular Genetics. 2014;23(9):2339-52. 
67. Izu Y, Adams SM, Connizzo BK, Beason DP, Soslowsky LJ, Koch M, et al. Collagen XII mediated cellular and extracellular mechanisms regulate establishment of tendon structure and function. Matrix Biology [Internet]. 2021;95:52-67. Available from: https://doi.org/10.1016/j.matbio.2020.10.004

68. Marro J, Pfefferli C, de Charles ASP, Bise T, Jaźwiñska A. Collagen XII contributes to epicardial and connective tissues in the zebrafish heart during ontogenesis and regeneration. PLoS ONE. 2016;11(10):1-23.

69. Härönen H, Zainul Z, Naumenko N, Sormunen R, Miinalainen I, Shakirzyanova A, et al. Correct expression and localization of collagen XIII are crucial for the normal formation and function of the neuromuscular system. European Journal of Neuroscience. 2019;49(11):1491-511.

70. Härönen H, Zainul Z, Tu H, Naumenko N, Sormunen R, Miinalainen I, et al. Collagen XIII secures pre- and postsynaptic integrity of the neuromuscular synapse. Human Molecular Genetics. 2017;26(11):2076-90.

71. Koivunen J, Tu H, Kemppainen A, Anbazhagan P, Finnilä MA, Saarakkala S, et al. Integrin $\alpha 11 \beta 1$ is a receptor for collagen XIII. Cell and Tissue Research. 2020;383(3):1135-53.

72. Luo Y, Sinkeviciute D, He Y, Karsdal M, Henrotin Y, Mobasheri A, et al. The minor collagens in articular cartilage. Protein and Cell. 2017;8(8):560-72.

73. Agarwal $P$, Zwolanek D, Keene DR, Schulz JN, Blumbach K, Heinegård D, et al. Collagen XII and XIV, new partners of cartilage oligomeric matrix protein in the skin extracellular matrix suprastructure. Journal of Biological Chemistry. 2012;287(27):22549-59.

74. Freise C, Bobb V, Querfeld U. Collagen XIV and a related recombinant fragment protect human vascular smooth muscle cells from calcium-/phosphate-induced osteochondrocytic transdifferentiation. Experimental Cell Research [Internet]. 2017;358(2):242-52. Available from: http://dx.doi.org/10.1016/j.yexcr.2017.06.018

75. Kong R, Liu H, Shi Y, Man Q, Liu S. COL14A1 promotes self-renewal of human liver cancer stem cells through activation of ERK signaling. Journal of Bio-X Research. $2021 ; 4(1): 10-7$.

76. Tao G, Levay AK, Peacock JD, Huk DJ, Both SN, Purcell NH, et al. Collagen XIV is important for growth and structural integrity of the myocardium. Journal of Molecular and Cellular Cardiology [Internet]. 2012;53(5):626-38. Available from: http://dx.doi.org/10.1016/j.yjmcc.2012.08.002

77. Lisignoli G, Lambertini E, Manferdini C, Gabusi E, Penolazzi L, Paolella F, et al. Collagen type XV and the 'osteogenic status.' Journal of Cellular and Molecular Medicine. 2017;21(9):2236-44.

78. Clementz AG, Mutolo MJ, Leir SH, Morris KJ, Kucybala K, Harris H, et al. Collagen $\mathrm{XV}$ inhibits epithelial to mesenchymal transition in pancreatic adenocarcinoma cells. PLoS ONE. 2013;8(8):1-10.

79. Durgin BG, Cherepanova OA, Gomez D, Karaoli T, Alencar GF, Butcher JT, et al. Smooth muscle cell-specific deletion of col15a1 unexpectedly leads to impaired development of advanced atherosclerotic lesions. American Journal of Physiology Heart and Circulatory Physiology. 2017;312(5).

80. Guillon E, Bretaud S, Ruggiero F. Slow muscle precursors lay down a collagen XV matrix fingerprint to guide motor axon navigation. Journal of Neuroscience. 2016;36(9):2663-76. 
81. Rygh CB, Løkka G, Heljasvaara R, Taxt T, Pavlin T, Sormunen R, et al. Image-based assessment of microvascular function and structure in collagen XV- and XVIIIdeficient mice. Journal of Physiology. 2014;592(2):325-36.

82. Tanimura S, Tadokoro Y, Inomata K, Binh NT, Nishie W, Yamazaki S, et al. Hair follicle stem cells provide a functional niche for melanocyte stem cells. Cell Stem Cell [Internet]. 2011;8(2):177-87. Available from: http://dx.doi.org/10.1016/j.stem.2010.11.029

83. Yodsurang V, Tanikawa C, Miyamoto T, Lo PHY, Hirata M, Matsuda K. Identification of a novel p53 target, COL17A1, that inhibits breast cancer cell migration and invasion. Oncotarget. 2017;8(34):55790-803.

84. Hurskainen T, Moilanen J, Sormunen R, Franzke CW, Soininen R, Loeffek S, et al. Transmembrane collagen XVII is a novel component of the glomerular filtration barrier. Cell and Tissue Research. 2012;348(3):579-88.

85. Kiritsi D, Kern JS, Schumann H, Kohlhase J, Has C, Bruckner-Tuderman L. Molecular mechanisms of phenotypic variability in junctional epidermolysis bullosa. Journal of Medical Genetics. 2011;48(7):450-7.

86. Duncan MB, Yang C, Tanjore H, Boyle PM, Keskin D, Sugimoto H, et al. Type XVIII collagen is essential for survival during acute liver injury in mice. DMM Disease Models and Mechanisms. 2013;6(4):942-51.

87. Aikio $M$, Hurskainen M, Brideau G, Hägg P, Sormunen R, Heljasvaara $R$, et al. Collagen XVIII short isoform is critical for retinal vascularization, and overexpression of the Tsp-1 domain affects eye growth and cataract formation. Investigative Ophthalmology and Visual Science. 2013;54(12):7450-62.

88. Kivinen N, Felszeghy S, Kinnunen Al, Setälä N, Aikio M, Kinnunen K, et al. Absence of collagen XVIII in mice causes age-related insufficiency in retinal pigment epithelium proteostasis. Biogerontology. 2016;17(4):749-61.

89. Kim SH, Kim YS, Lee SY, Kim KH, Lee YM, Kim WK, et al. Gene expression profile in mesenchymal stem cells derived from dental tissues and bone marrow. Journal of Periodontal and Implant Science. 2011;41(4):192-200.

90. Oudart JB, Monboisse JC, Maquart FX, Brassart B, Brassart-Pasco S, Ramont L. Type XIX collagen: A new partner in the interactions between tumor cells and their microenvironment. Matrix Biology [Internet]. 2017;57-58:169-77. Available from: http://dx.doi.org/10.1016/j.matbio.2016.07.010

91. Su J, Cole J, Fox MA. Loss of interneuron-derived collagen XIX leads to a reduction in perineuronal nets in the mammalian telencephalon. ASN Neuro. 2017;9(1).

92. Misawa K, Kanazawa T, Imai A, Endo S, Mochizuki D, Fukushima $\mathrm{H}$, et al. Prognostic value of type XXII and XXIV collagen mRNA expression in head and neck cancer patients. Molecular and Clinical Oncology. 2014;2(2):285-91.

93. Jakobsen JR, Mackey AL, Knudsen AB, Koch M, Kjær M, Krogsgaard MR. Composition and adaptation of human myotendinous junction and neighboring muscle fibers to heavy resistance training. Scandinavian Journal of Medicine and Science in Sports. 2017;27(12):1547-59.

94. Feng C, Chan WCW, Lam Y, Wang X, Chen P, Niu B, et al. Lgr5 and Col22a1 mark progenitor cells in the lineage toward juvenile articular chondrocytes. Stem Cell Reports [Internet]. 2019;13(4):713-29. Available from: https://doi.org/10.1016/j.stemcr.2019.08.006 
95. Charvet B, Guiraud A, Malbouyres M, Zwolanek D, Guillon E, Bretaud S, et al. Knockdown of col22a1 gene in zebrafish induces a muscular dystrophy by disruption of the myotendinous junction. Development. 2013;140(22):4602-13.

96. Ton Q v., Leino D, Mowery SA, Bredemeier NO, Lafontant PJ, Lubert A, et al. Collagen COL22A1 maintains vascular stability and mutations in COL22A1 are potentially associated with intracranial aneurysms. DMM Disease Models and Mechanisms. 2018;11(12).

97. Veit G, Zwolanek D, Eckes B, Niland S, Käpylä J, Zweers MC, et al. Collagen XXIII, Novel Ligand for Integrin $\alpha 2 \beta 1$ in the Epidermis. Vol. 286, The Journal of biological chemistry. 2011. p. 27804-13.

98. Wang W, Olson D, Liang G, Franceschi RT, Li C, Wang B, et al. Collagen XXIV (Col24a1) promotes osteoblastic differentiation and mineralization through TGF$\beta /$ Smads signaling pathway.pdf. Int J Biol Sci. 2012;8(10):1310-1322.

99. Gonçalves TJM, Boutillon F, Lefebvre S, Goffin V, Iwatsubo T, Wakabayashi T, et al. Collagen XXV promotes myoblast fusion during myogenic differentiation and muscle formation. Scientific Reports. 2019;9(1):1-12.

100. unezane H, Oizumi H, Wakabayashi T, Nishio S, Hirasawa T, Sato T, et al. Roles of collagen XXV and its putative receptors PTP $/ \delta$ in intramuscular motor innervation and congenital cranial dysinnervation disorder. Cell Reports [Internet]. 2019;29(13):4362-4376.e6. https://doi.org/10.1016/j.celrep.2019.11.112

101. rumezescu AM, editor. Nanobiomaterials in Soft Tissue Engineering: Applications of Nanobiomaterials [Internet]. Belanda: Elsevier Science; 2016. Available from: https://books.google.co.id/books?id=NpNCCQAAQBAJ

102. Plumb DA, Ferrara L, Torbica T, Knowles L, Mironov A, Kadler KE, et al. Collagen XXVII organises the pericellular matrix in the growth plate. PLoS ONE. 2011;6(12).

103. chiller HB, Fernandez IE, Burgstaller G, Schaab C, Scheltema RA, Schwarzmayr $\mathrm{T}$, et al. Time- and compartment-resolved proteome profiling of the extracellular niche in lung injury and repair. Molecular Systems Biology. 2015;11(7):819.

104. riffiths C, Barker J, Bleiker TO, Chalmers R, Creamer D, editors. Rook's Textbook of Dermatology [Internet]. Jerman: Wiley; 2016. Available from: https://books.google.co.id/books?id=EyypCwAAQBAJ

105. lager DA, Torres SMF, Koch SN, Kita H. Gene transcription abnormalities in canine atopic dermatitis and related human eosinophilic allergic diseases. Veterinary Immunology and Immunopathology [Internet]. 2012;149(1-2):136-42. Available from: http://dx.doi.org/10.1016/j.vetimm.2012.06.003

106. Widayati E. Oxidasi biologi, radikal bebas, dan antioxidant. Majalah IImiah Sultan Agung. 2012;50(128).

107. ain P, Pandey R, Shukla SS. Inflammation: Natural Resources and Its Applications [Internet]. India: Springer India; 2014. Available from: https://books.google.co.id/books?id=OXq1BQAAQBAJ

108. Felson DT, Schaible HG, editors. Pain in Osteoarthritis [Internet]. Jerman: Wiley; 2010. Available from: https://books.google.co.id/books?id=DFTjbbMizRYC

109. Oguntibeju $O$, editor. Antioxidant-antidiabetic Agents and Human Health [Internet]. Kroasia: IntechOpen; 2014. Available from: https://books.google.co.id/books?id=MyqhDwAAQBAJ 
110. Adjei AA, Buolamwini JK, editors. Novel Anticancer Agents: Strategies for Discovery and Clinical Testing [Internet]. Belanda: Elsevier Science; 2011. Available from: https://books.google.co.id/books?id=75t2-XiMJgMC

111. Ficai A, Grumezescu AM, editors. Nanostructures for Antimicrobial Therapy [Internet]. Belanda: Elsevier Science; 2017. Available from: https://books.google.co.id/books?id=wM78DAAAQBAJ

112. Giampapa VC. The Principles and Practice of Antiaging Medicine for The Clinical Physician [Internet]. Denmark: River Publishers; 2013. Available from: https://books.google.co.id/books?id=GW1N76tPIwUC

113. Juncan $A M$, Lung $C$. Formulation and optimizing of a anti-aging cosmetic cream. Studia UBB Physica [Internet]. 2016;61(LXI):101-10. Available from: http://studia.ubbcluj.ro/download/pdf/physica/2016_2/11.pdf 